\title{
Small States and the European Union
}

An investigation of discourse and its consequences for the relationship with the EU in five small European states. 
Size is not grandeur, and territory does not make a nation.

Thomas Huxley - English Biologist 


\section{Abstract}

This study considers the small states and state like entities of Europe, defined as those with a population of fewer than 2 million, and their relationship with the EU. It focuses on Andorra, Iceland, Luxembourg, Jersey and Åland and is conducted using interviews with 'non experts' in each of these states. This data is supplemented with expert interviews in each state to establish the nature of the informal relationship between the EU and the state. The concept of discourse is a central theory in this work; and the content of the discourse in each state is examined and conclusions are drawn as to how this discourse has affected the possible relationships with the EU. This thesis finds that discourses of identity are of great importance in determining the possibility of changes in relationships between the EU and the small states, however once these discourses are resolved discourses of economics, security, size and practicality become more important.

Key words: Small States, EU Integration, Discourse, Microstates, State Like Entities

Words: 18,644 


\section{Table of contents}

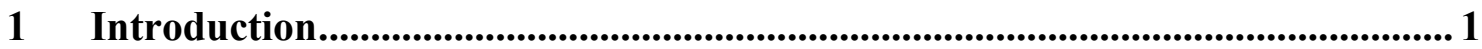

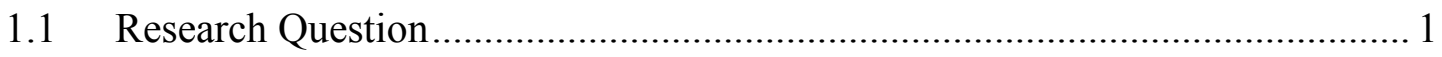

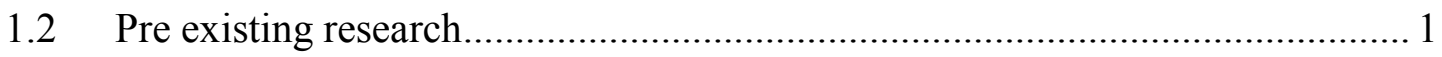

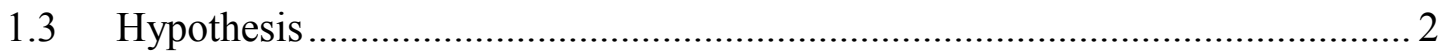

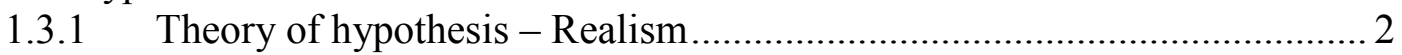

1.3.2 Theory of hypothesis - Liberalism........................................................ 3

1.3.3 Theory of hypothesis - Constructivism .............................................. 4

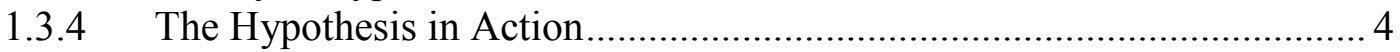

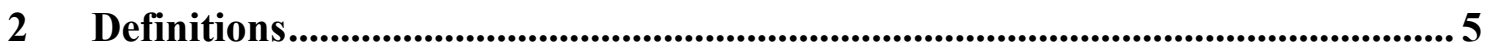

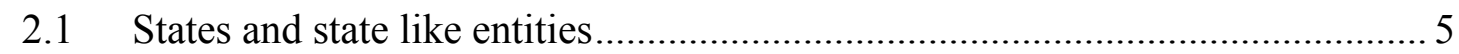

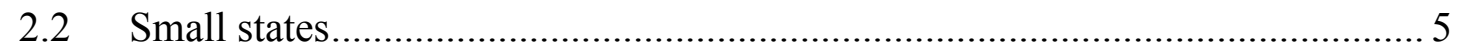

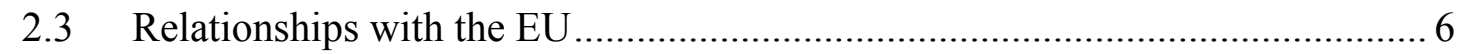

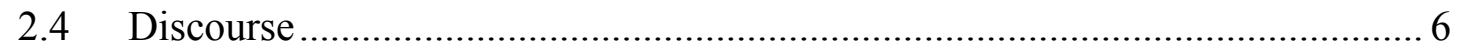

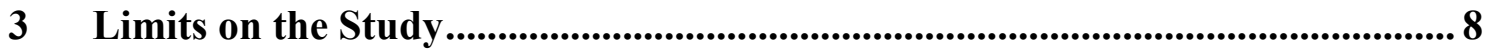

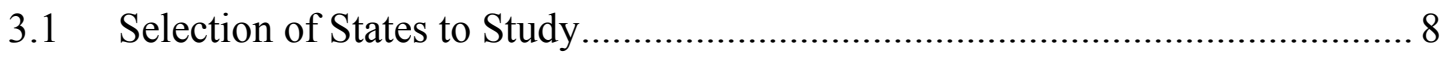

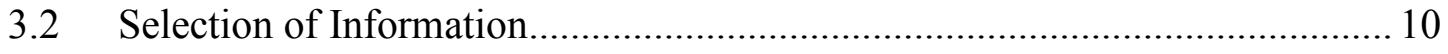

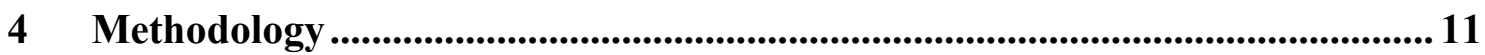

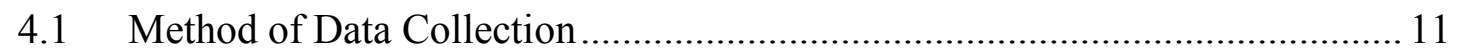

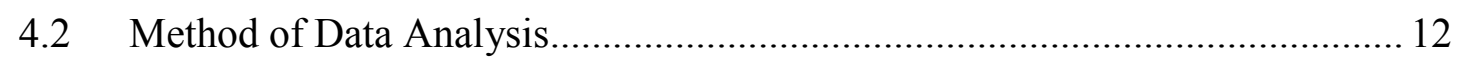

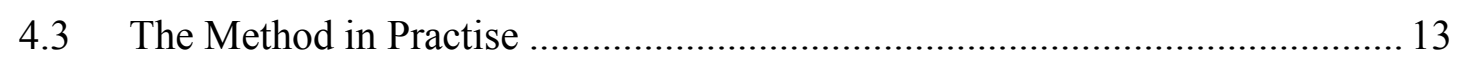

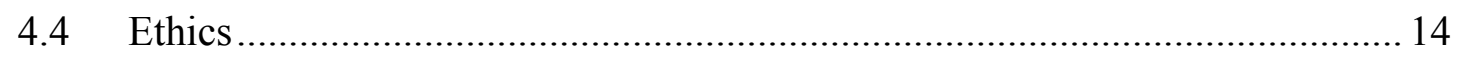

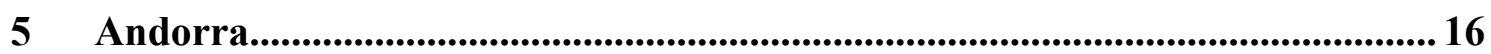

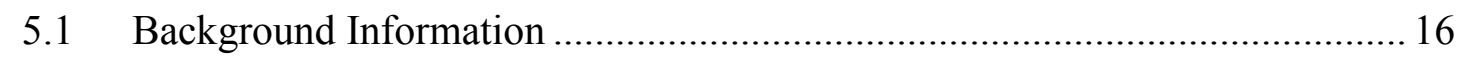

5.2 Formal Relationship with the EU ............................................................. 17

5.3 Informal Relationship with the EU .......................................................... 17

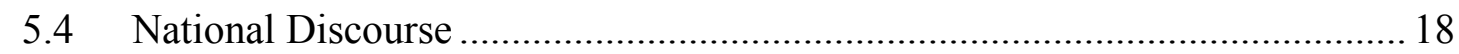

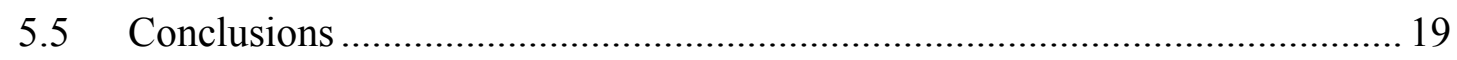

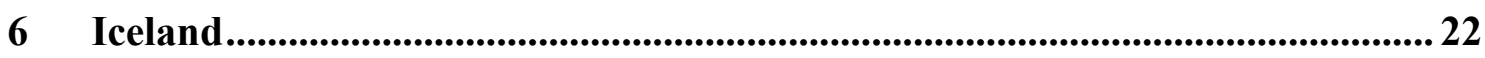

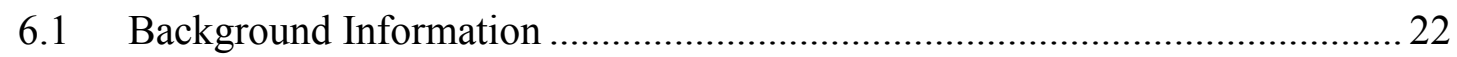

6.2 Formal Relationship with the EU ............................................................. 23 


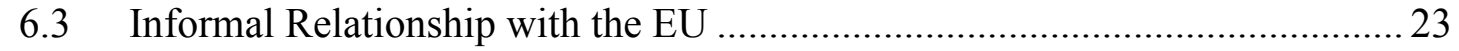

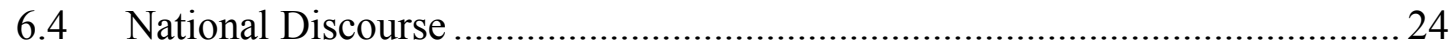

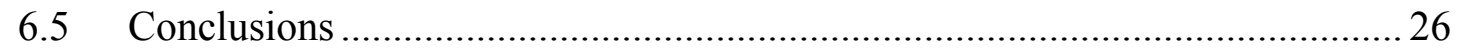

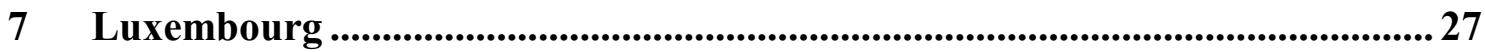

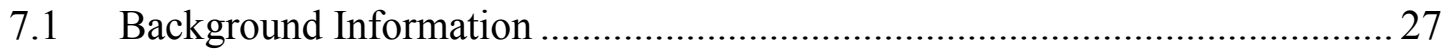

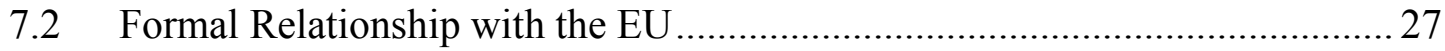

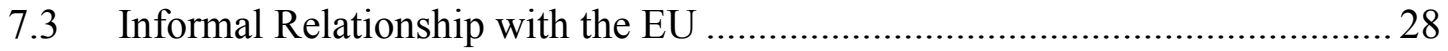

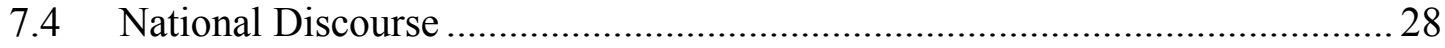

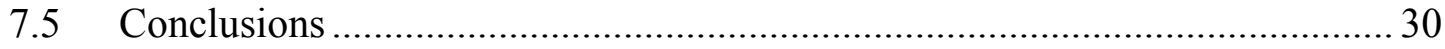

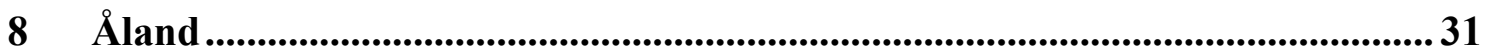

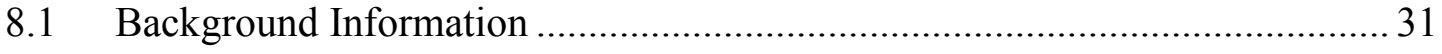

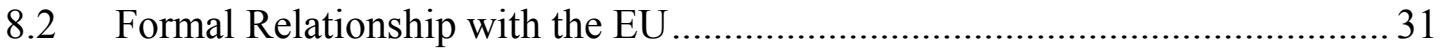

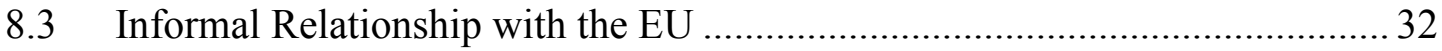

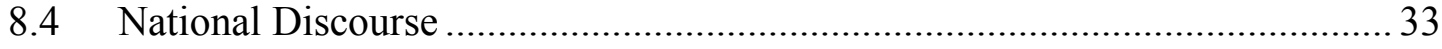

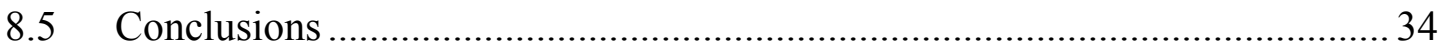

9 Jersey

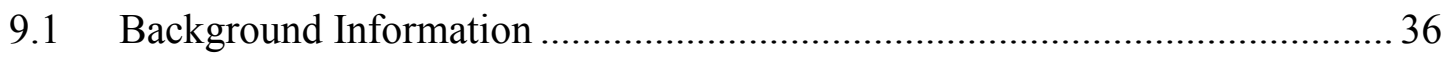

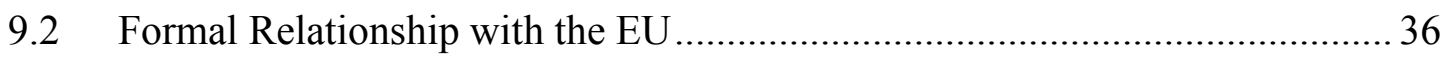

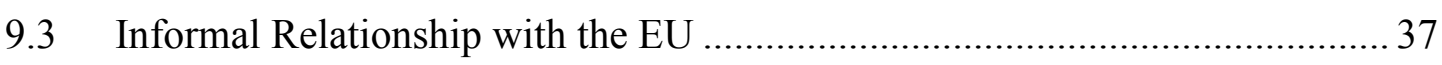

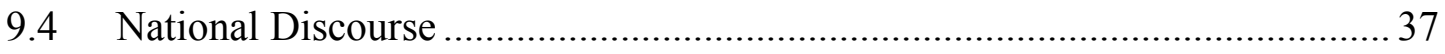

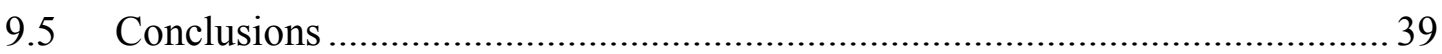

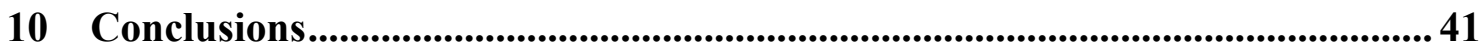

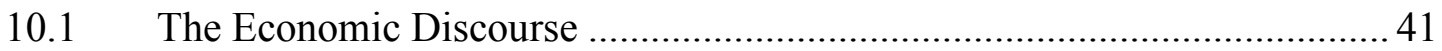

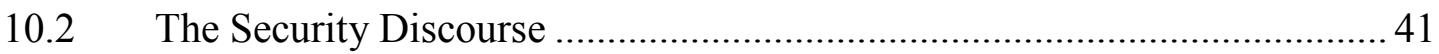

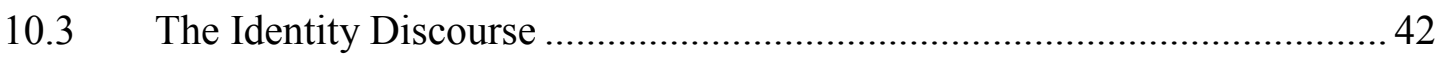

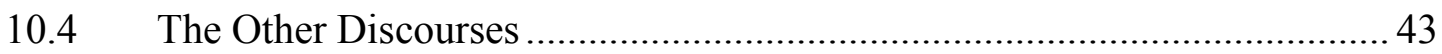

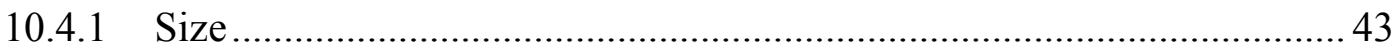

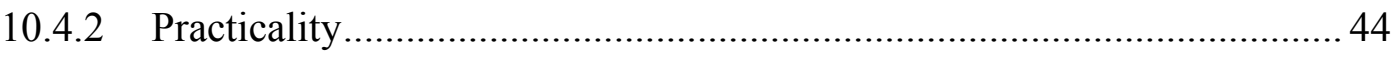

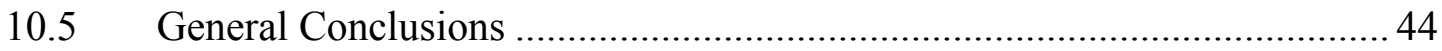

10.6 Examination of the Hypothesis ............................................................. 45

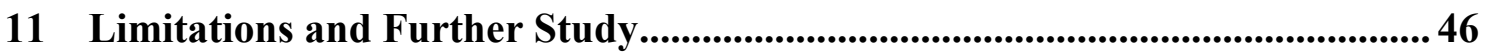

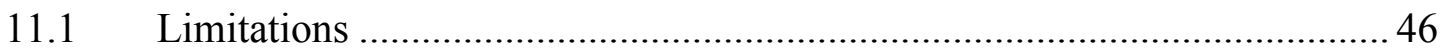

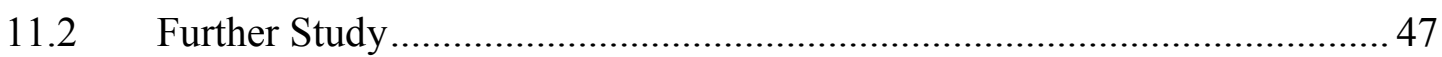




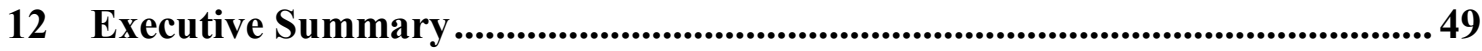

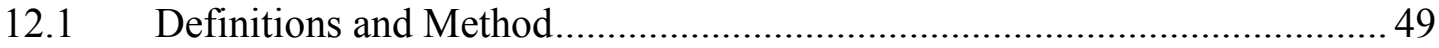

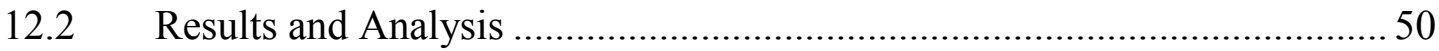

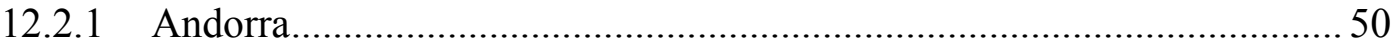

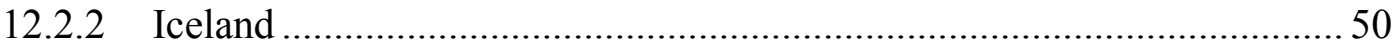

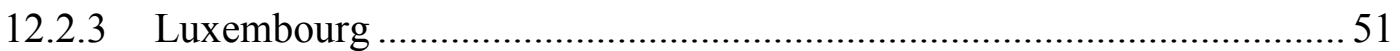

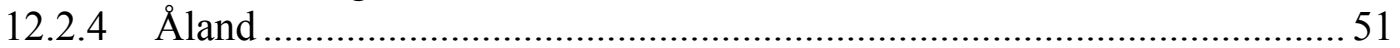

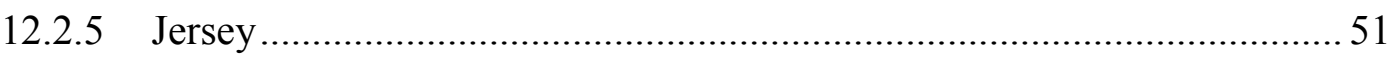

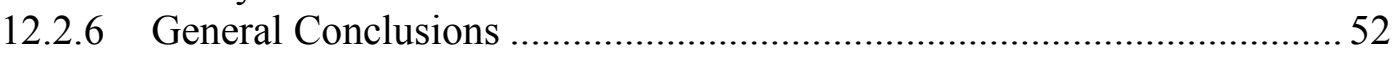

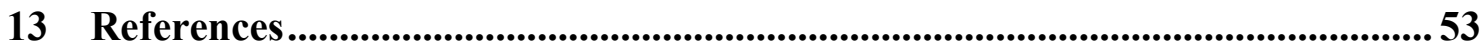




\section{Introduction}

\subsection{Research Question}

This thesis seeks to address the question of what is the content of discourse within small states in Europe about the EU and how has that discourse has affected relationships with the EU?

The thesis begins with a very brief overview of existing literature and then goes on to establish the hypothesis that the work of this thesis will be based upon. This is followed by definitions of the terms under study and the limits of the study accompanied by a more detailed discussion of the methodology that the study will use. There are then country specific chapters that discuss the question above in relation to each of the states, and another chapter discussing the states in comparison with each other. The thesis concludes with a discussion of the limitations of the work and the areas for possible further study.

\subsection{Pre existing research}

This very brief overview of small state literature seeks to demonstrate that this thesis provides an insight into an area that has not been well studied previously. Generally small state research has focused on an analysis of capacity, or lack of capacity of small states to act on the international stage and in international organisations. Many authors have discussed this area including Morgenthau (1972, 129-130), 'A Great Power is a state which is able to have its will against a small state', Kagan (2003), Kennedy (1991) and Watson (1982). This thesis does not seek to address state capability except for where it forms part of a national discourse. While understanding state that capacity is important this area of study it has been well researched previously and is not the main focus of this thesis. This thesis considers instead the state's decisions about integration into the EU. Here self perception of compatibility and perceived economic benefits are as important as the ability to play a role in influencing the security environment.

The other main preoccupation of small state research has been the definition of small states. Definitions have ranged from using purely quantitative measures of population, economy or size, usually combined in some form of metric to 
qualitative measures. The purely qualitative measures tend to look at state self perceptions of size or external perceptions of state size or influence. Most researchers have combined both these types of measures to reach a definition. Examples of all three can be found in Vayrynen (1971), Crowards (2002a) and Neuman \& Gstöhl (2004) amongst others. The emphasis however in these works is generally towards the quantitative approach since it produces clear lines about what is a small state. The discussion of how this thesis defines small states can be found in the definitions section. This thesis is seeking to start to fill the gap in small state research that deals with the actual discourse and politics within small states and tells us about how a certain important issue is viewed in a set of overlooked countries. The definitions section below gives a public administration definition of small states. This definition provides the scientific underpinning for studying very small states but it is also worth nothing that these very small states are often neglected in other academic studies of small states or merely serve as an adjunct to the main debate.

\subsection{Hypothesis}

The thesis is based on theory and seeks to develop an analytical structure based on existing theories but without being tied to one theoretical school. The three main schools of international relations thought have been used as the source of the three themes used in the hypothesis. The three schools of Realism, Liberalism and Constructivism give rise to the three themes of Security, Economics and Identity. The origins of these themes are discussed below. The hypothesis generated is that,

'Small states seek to join the EU when questions of Security, Economics and Identity have been addressed. Once these three factors have been satisfactorily addressed in the National discourse then the state will seek membership of the EU.'

The contribution of each of the theories is examined below:

\subsubsection{Theory of hypothesis - Realism}

Realism describes how smaller states are subject to seeking a multi-lateral security environment, because 'international institutions make resource-based power effects more visible because norms and rules are formalized and thus require justification' (Neuman and Gstöhl 2004, 2). This prevents small states from being forced into positions they find unfair, it 'levels the playing field'. In Europe the main multi-lateral institution under discussion is the European Union, however it must be born in mind that in the security area NATO is also of crucial importance. When considering why states seek integration with the EU the importance of power relations can not be forgotten. Small states lack power in 
realist terms; they can not set the rules of the game and are subjected to the whims of the larger states that dominate the international environment. This would lead to the question of why small states would want to join a multi-lateral organisation with large powers who would surely dominate this environment? Mouritzen and Wivel (2005) seek to nuance this discussion by looking at small states in the European system. They establish a principle of institutional affiliation with the great powers which leaves differing 'room for manoeuvre' in foreign policy terms (Thorhallsson and Wivel 2006, 656). The difference in 'room for manoeuvre' relates directly to how close they are to the power centre of the EU and the related ability to influence the power centre of the EU. The discussion of EU membership has often involved discussions of the security implications, for example Sweden, Austria and Finland's decision to join the EU after the fall of communism (Ingebritsen 2006, 11-13), or the recent debate about common foreign and security policy in Ireland around the Lisbon treaty (Cole 2009).

This theoretical background gives rise to the theme of 'security' in the analysis. The security under consideration here is what is often called 'hard' security it is the ability of the state to protect its own boarders and citizens from attack by an external power. The examples from larger states show that security has played a role in decisions of some states in their relationship with the EU; it remains to be seen if the smaller states of Europe also consider these sorts of questions or if other factors arise.

\subsubsection{Theory of hypothesis - Liberalism}

Liberal theory highlights the importance of domestic pressure groups in the formulation of EU policy. Here the relationship sought by each state is dominated by its key industries. Christine Ingebritsen (1998) identifies how Nordic states' approaches to integration are dominated by their key industries; she gives the examples of Sweden's auto makers wanting access to the European market, while Norwegian farmers seek to protect their special status and high funding in Norway; thus leading Sweden to join the EU, and Norway to reject membership. This economically driven understanding of European integration is important when considering that small states tend to be, as Katzenstein (1995) argues, more corporatist, thus the industry and labour groups are more involved in government decision making. The involvement of key sectoral interests in the policy formation process means that the dominant local industries have relatively more power within smaller states when compared to larger states. Katzenstein additionally argues that small states are export oriented due to their economic specialisation and therefore open markets are of great benefit to them, thus the EU as an economic project is highly attractive. He argues that the reason for small states in particular to favour open markets is that they have a small production base thus export earnings are needed for vital imported goods and external markets are 
needed to consume domestic production. He argues there is a clear advantage to small states to accessing larger markets in the way the EU offers.

These ideas give rise to the theme of 'economy' in the analysis. The economic analysis is looking at the way the discourse views the potential for engagement with the EU to positively or negatively affect the state's economy.

\subsubsection{Theory of hypothesis - Constructivism}

Constructivism identifies the importance of identity in understanding the approach to integration. Here the key factor is the compatibility of the national discourse on integration with the European Project with the local discourses of identity. In addition constructivist theories have been used to explain enlargement of the EU in terms other than economics. Denmark was highly supportive of enlargement of the EU; this support was largely based on a discourse of peace building within the continent of Europe not on economic or other 'rational' grounds (Riddervold and Sjursen, 2006).

For small states, size is often part of the national discourse. It becomes a factor in explaining an approach to the EU because size can affect the discourse of integration, either in favour of or against membership of the EU, the analysis of the data from Iceland provides an interesting example of both of these cases. In addition cultural factors such as history and national identity can be mixed with size and thus shape the debate in each state.

This theory gives rise to the analytical theme of identity. The discourse within the discourse must be considered; in some cases perceived 'rational' choices about engagement with the EU may be based on a normative or cultural attachment or antipathy to the notion of Europe.

\subsubsection{The Hypothesis in Action}

The above theories have been used, as previously stated to create the hypothesis that, 'Small states seek to join the EU when questions of Security, Economics and Identity have been addressed. Once these three factors have been satisfactorily addressed in the National discourse then the state will seek membership of the EU.' This is coupled with the research question on the content of discourses in small states to create the research project for this thesis. The following methods section explains in detail how the thesis will gather and analyse data to answer the research question. The final conclusions section will return to the theory generated hypothesis and analyse if and how a new hypothesis should be reformulated. 


\section{Definitions}

\subsection{States and state like entities}

For the purpose of this thesis states have been defined as the 192 states registered at the United Nations. This simple definition has been chosen to avoid the more complex definitions and discussion of what a state is. State like entities have been defined as areas which while not formally independent, but have a high degree of autonomy and have chosen their relationship with the EU independently from the rest of the state they are part of.

\subsection{Small states}

For the purpose of this thesis small states have been defined as states with a population of less than two million. There are many definitions of small states that are used in academic literature. The measures of size range from purely quantitative, mixed and purely qualitative measures. This discussion while highly useful will not be the main focus of this thesis. ${ }^{1}$ These approaches have generally defined small states in terms of their influence in international relations or international political economy; however for my thesis I propose to use the limit suggested by Tiina Randma-Liiv (2002). In her work she suggests that states with a population of under two million people have different types of public administration. The smaller 'size of the society' in these states affects the way public administration functions and therefore how the small states act on the European stage. The argument presented here is that these small states are not like large states in miniature but are qualitatively different, the importance of individuals and personal relations is greater, there is a need for a different more flexible style of public administration and a higher degree of personalism and multi functional job roles. Thus the classical understanding of reasons for taking part in the European Integration project may not apply.

\footnotetext{
${ }^{1}$ This discussion can be found in much more details in works by Vayrynen (1971), Crowards (2002a) and Neuman \& Gstöhl (2004) amongst others.
} 


\subsection{Relationships with the EU}

One of the variables under study is the relationships that the states and state like entities have with the EU and the content of discourse within each state, or state like entity. The relationships are easy to define on a formal level since they are governed by treaty arrangements and thus have a legal basis that can be pointed to, each section below dealing with the states details the formal treaty arrangements between the state and the EU. However, the informal relationships between the EU and some of the states are slightly harder to define. This second concept of 'informal relationships' must therefore be defined. For this thesis the informal relationships include the informal communications and consultations between the EU and the states or state like entities and the non codified arrangements between the EU and the states or state like entities. It also includes the ways in which the states seek to influence the EU's decision making process outside of the formal channels of bilateral communication, in other words, how the states lobby the EU.

\subsection{Discourse}

This thesis draws its definition and rationale for studying discourse from the work of Michelle Foucault. Foucault's definition of discourse allows us to say that a discourse is so pervasive through a society that it is impossible for most members of that society to view the subject of the discourse in any way other than those permitted by the discourse. Discourse in Foucault's model has been described as 'systems of thoughts composed of ideas, attitudes, courses of action, beliefs and practices that systematically construct the subjects and the worlds of which they speak' (Lessa 2006). For Foucault (1977) Discourse is the, 'medium through which power relations produce speaking subjects'. In the case of this thesis the production of the discourse is not the area of interest, the area of interest is the content of the discourse. An assumption is made that the general population of each state are subject to the national discourse and thus studying how each population constructs their ideas about the EU will tell us about the discourse in each state.

The Foucladian definition does not allow the individual who is using the discourse to view the object of discourse, in this case the relationship of the state and the EU, from outside the discourse. 'Foucault claims it is not possible to gain access to universal truth since it is impossible to talk from a position outside discourse,' (Jorgensen and Phillips $(2002,14)$ thus, interviews with 'non experts' are more likely to uncover the true nature of the discourse than interviews with 'experts' who will have outside academic frames that the relationship with the EU is viewed through. The social constructivist view of Foucault, 'that knowledge is not 
just a reflection of reality' Jorgensen and Phillips (2002, 13), is central to the thesis. By assuming that knowledge reflects the social context in which it is gained, this thesis assumes that by studying the 'knowledge' of the population of small states we can learn something about the social reality in which that 'knowledge' is gained. The use of quotes around the world 'knowledge' aims to indicate that all knowledge is subjective and is subjected to social construction and therefore should be understood as a product of the social context not as simple abstract fact that can be interpreted independently of the context from which it was gained.

Thus this thesis which is examining the nature of the discourse about the EU within each of the small states or state like entities uses the Fouclaudian definition of discourse to allow a generalisation from the individuals interviewed to a statement of what the national discourse on the issue is. 


\section{Limits on the Study}

\subsection{Selection of States to Study}

The first limit that must be imposed on the study for practical reasons is the number of states and state like entities to be studied. To find a rational and scientific way to limit the number of states and state like entities under study they have been placed into groups based on their formal relationship with the EU.

EU member states:

Malta, Luxembourg, Cyprus, Estonia, Slovenia

EU applicant states:

Montenegro

EFTA states:

Lichtenstein, Iceland

States with a bilateral arrangement with the EU:

Andorra, San Marino, Monaco, the Vatican

As the relationships of the state like entities are not the same as the states under study they have been grouped separately here.

Part of an EU member state and part of the EU:

Aland, Gibraltar

$\underline{\text { Part of an EU member state, but not part of the EU: }}$

Faeroe Islands, Guernsey, Isle of Man, Jersey 


\section{Part of a non EU member state:}

\section{Jan Mayern and Svalbard}

The same problem remains in selecting a feasible number of states to study from this list. Thus, it has been decided to apply an initial limit of studying only Western European states and state like entities. The rationale for limiting to Western Europe is that these states have been able to engage in the European Integration project for a longer period of time and therefore it is worth asking the question why some have engaged and other not engaged. This limit removes Cyprus, Estonia and Slovenia from the EU member states category and removes the only applicant state since Montenegro is the only state in this category. The list of state like entities remains unchanged. To further refine the list, for practical reasons, the state like entities that are part of a non EU member state will not be included as they are so sparsely populated and difficult to get access to.

Thus, taking into account practical travel restrains and the need for as broad a mix of states as possible the following states have been chosen for study.

The EU member state selected for inclusion in the study is Luxembourg. The reason for selecting Luxembourg is that it is the only long standing member of the EU in the sample and thus gives a useful comparison to compare with the other states.

From the EFTA states Iceland has been selected because the current political and economic changes there demonstrate the changeability of discourse during a crisis.

From the states with a bilateral relationship with the EU Andorra has been chosen for inclusion in the thesis. Since each state in this group has a unique difference in its relationship to the EU and thus are all interesting cases for different reasons. Initially practical constraints of travel ruled out San Marino and The Vatican has a very low permanently resident population and is such a 'strange' political entity it was decided not to include it in the study. This left Monaco and Andorra for possible inclusion. Andorra has been selected for study because of its different nature of relationship to the EU when compared to the other states under study. The mediation of its formal relationship with the EU by Spain and France and the tolerance but lack of approval for use of the Euro by the EU were all reasons for warranting its choice of inclusion in the study.

From the state like entities that are part of an EU member state and part of the EU Åland has been selected on practicality of travel grounds and to avoid two British dependencies being included in the study. 
From the states that are part of an EU member state but not part of the EU, the state selected is Jersey. Once again practical considerations have been taken into account, and as the largest of the three Crown Colonies ${ }^{2}$ it is an interesting case.

This leaves the following states and state like entities as being included in the study:

Luxembourg, Iceland, Andorra, Åland and Jersey.

From this point on any reference to 'the small states' or 'the states' can be understood to mean the 3 small states and 2 state like entities that are listed here.

\subsection{Selection of Information}

The other limitation that must be applied to the study is that of informational availability. The informal relationship between the EU and the states poses a difficulty in finding information as the very nature of these types of relationships are that they are not documented or easily accessible to those outside of high level relationships. Thus the caveat that information on the relationships between the EU and the states is almost definitely incomplete must be borne in mind. The method, detailed below, requires contact with people in the states. This is not always practicable for time and cost reasons and the method details what steps will be taken where it is not found feasible to travel to the states.

The thesis applies no strict time limit to understanding the relationships of the EU and the states; however, it must be borne in mind that the discourse under study is the discourse of today. Discourses can and often do change over time so historical data will be relevant where it is part of the discourse but will not be the main focus of understanding the discourses that are analysed.

\footnotetext{
${ }^{2}$ Crown Colonies are British Dependencies that have full internal self governance, however the Queen is the head of state and Westminster handles the foreign affairs and guarantees the security of the islands. The citizens of the crown colonies are not UK citizens and thus do not have access to all rights of UK citizens.
} 


\section{Methodology}

This thesis seeks to address the question of what is the content of discourse within small states in Europe about the EU and how that discourse has affected relationships with the EU.

It is clear that there are two parts to the question, firstly the content of discourse in the states; and secondly, the way that the discourse has effected relationships with the EU.

\subsection{Method of Data Collection}

The collection of data will consist of establishing the formal relationship between the EU and the states and what that means in practise for the three states that are not part of the EU. In tandem with this is the need to gather what available data there is on the non-formal relationships. This will take the form of reviewing news coverage of the relationships and contacting diplomats from the states to find out how the formal relationship functions in reality. These contacts will, in methodological terms, be expert interviews. However, as the nature of these relationships is not the main focus of the thesis a limited amount of space will be devoted to this topic.

The second aspect of data collection is the collection of data about the content of discourses. The ideal form of collecting this data will be by travelling to the states and conducting informal semi-structured interviews with 'non experts'. The use of the term 'non experts' is not meant to imply a lack of knowledge on behalf of the individuals interviewed but merely to indicate that these people will not be selected for their specialised knowledge of the EU of their states relationship with the EU. The rationale behind this is drawn from the definition of discourse being used by this thesis which is discussed in the definitions section.

At this point a brief discussion of generaliseability of results based on this data must be entered into. Data based on the small number of interviews that will be possible can not be considered representative in most circumstances, however since the discourse under study is an all pervading concept if there are stable patterns across the interviews it is possible to conclude that this discourse is 
dominant within the society, subject to the caveats that data may be skewed by availability of people who speak English and by an effect of travelling predominantly to large urban centres in the states. These limitations will be discussed in more detail in the final limitations and further study section of the thesis.

As indicated earlier there is a potential limit on information availability for practical reasons. Thus the reserve option of interviews with experts must be considered, these experts will include politicians, media representatives and academic experts on the relationship between the EU and the state. The use of expert interviews will be held in reserve and conducted only if it is unavoidable in the analysis of the discourse. However, expert interviews will be the main source of knowledge for the sections on the relationship between the EU and the state.

The main method of data collection will be Interviews; Steinar Kvale (1996, 3-8) presents the idea of an interviewer as a 'miner' or as a 'traveller'. In his archetype the miner is conducting a positivist type interview and looking to 'unearth' the truth from careful questioning. The traveller metaphor is more useful in the case of this thesis as here the interviewer communicates with those that are met on 'his travels'. Thus data can be found from conversations with people, as this thesis seeks to examine discourses; conversations with people will be the main source of data. The interviews will follow the pattern of, 'an interview who's purpose is to obtain descriptions of the life world of the interviewee with respect to interpreting the meaning of the described phenomena.' Thus the phenomenon under study is the EU and its relationship with the interviewee's home country. The life world is the discourse that has shaped their views of this and their descriptions will give insight into the content of that discourse. Thus interviews will not follow a strictly set pattern but will have a topic focus that responds to the interviewee's own answers.

In addition to these 'non-expert' interviews, expert interviews will be used to establish the informal relationships between the states and the EU. These relationships will be examined with senior figures who have knowledge of the relationship. As Flick $(2006,165)$ argues an expert interview is generalisable because the expert represents a 'certain field of activity' and therefore is of general interest for their knowledge of this field and not as individuals with a particular point of view.

\subsection{Method of Data Analysis}

Data analysis will be conducted using an analytical frame drawn from the theory that informs the hypothesis. The data collected in the interviews will be taken down in the form of notes. These notes will be re written shortly after the 
interview to allow for the inclusion of reflections gained from the interview at the time.

The three themes that have been described in the hypothesis will form the basis of the analytical frame work. Thus the data will be analysed for statements that have been made that relate to these three themes. A fourth analytical category of statements that are not in the three themes will also be used. This fourth category will then be re-analysed to look for recurring themes. This fourth category is essential to the method to ensure that themes that fall outside the analytical frame work and may be more powerful explanatory factors are not neglected.

\subsection{The Method in Practise}

Before presenting the results of the research it is of value to present a brief review of the actual method used. Travel to all the states was possible and therefore the data on the discourses below is based on interviews conducted in each state. All the interviews were noted using pen and paper and any direct quotes are indicated in the text with quotation marks and summaries of interview content are never put into quotation marks. The nomenclature chosen for the 'non experts' is that of interviewees, thus in the data presented below 'the interviewees' refers to the 'non expert' interviews that were conducted in each state. The reason for abandoning the term 'non expert' is two fold, firstly it sounds inappropriately pejorative and detracts from the content and validity of the data, and secondly it is awkward to use this term continuously in fluent English therefore interviewees is more appropriate.

The table below indicates the number of interviews and locations at which the interviews took place. The implications of the numbers of interviews and the location those interviews took place is discussed in the limitations section of the thesis.

\begin{tabular}{|l|l|l|l|}
\hline State & $\begin{array}{l}\text { Number of } \\
\text { Interviews }\end{array}$ & $\begin{array}{l}\text { Number of Locations } \\
\text { in Capital City }\end{array}$ & $\begin{array}{l}\text { Number of } \\
\text { Locations outside } \\
\text { Capital City }\end{array}$ \\
\hline Luxembourg & 18 & 4 & 0 \\
\hline Iceland & 20 & 5 & 2 \\
\hline Andorra & 17 & 3 & 2 \\
\hline Jersey & 28 & 4 & 2 \\
\hline Åland & 14 & 2 & 0 \\
\hline
\end{tabular}

Table 1.1 - Table indicating the number and location of interviews. 
The interviews in each state were of the semi-structured type, meaning that they focused on a 'concrete issue' but the scope for 'response is left open' (Fick 2006, 150). The basic interview schedule consisted of 3 questions, which were:

- 'What did the interviewee feel were the positive aspect of their state's relationship with the EU?'

- 'What did the interviewee feel were the negative aspect of their state's relationship with the EU?'

- 'Did the interviewee wish to see any change in the relationship with the EU, and if so what type of change?'

It should be noted that the wording above is a general wording and questions were asked in a nation specific form each time, for example in the case of Iceland the first question was, 'what do you feel are the positive things for Iceland from being outside the EU.' In addition each interview started with a very brief outline of what was being studied and gave the interviewees a realistic idea of how long each interview would take.

These three questions alone were not all that was asked, careful use of non leading questions to explore the ideas generated in response to each of these questions were used to gather more data about the topics that the interviewee brought up, however at no point were topics introduced that the interviewee did not generate themselves. This is to ensure that the discourse is not contaminated with the researchers ideas of what should or could be present in the national discourse under consideration.

The expert interviews were conducted in person and by telephone. The expert interviews for Iceland and Andorra were done in Brussels in person, while those for Jersey and Åland were done by telephone. The difference between the two was simply for practical reasons of being able to arrange the interview while research was being conducted was in each state. The quality of data gathered from both is of equal value and has been noted and analysed in the same way.

\subsection{Ethics}

All research must consider the ethical implications of the work. The nature of this sort of research is that the potential for causing harm is low, however as the research involves interviewing both 'experts' and 'non experts' the question of, is the potential damage to the parties mitigated to the largest degree and not of significant concern enough to preclude conducting the research?

The risk to expert interviewees is in terms of being an identifiable source in the final work. All the experts will be given the option to remain anonymous, which it 
is assumed many will chose, and to have control of how the interview is recorded, or notated. They will be offered the chance to review sections of the work before it is submitted and to have any inaccuracies corrected before they are attributed to them. The 'non expert' interviewees will not be identified and thus face less personal risk. The interviews will be conducted in a public place and all interviewees will be able to end an interview at their choosing and will not be expected or asked to provide any reasons for doing so. Should a 'non expert' interviewee request that any comment not be used their request will be respected. 


\section{Andorra}
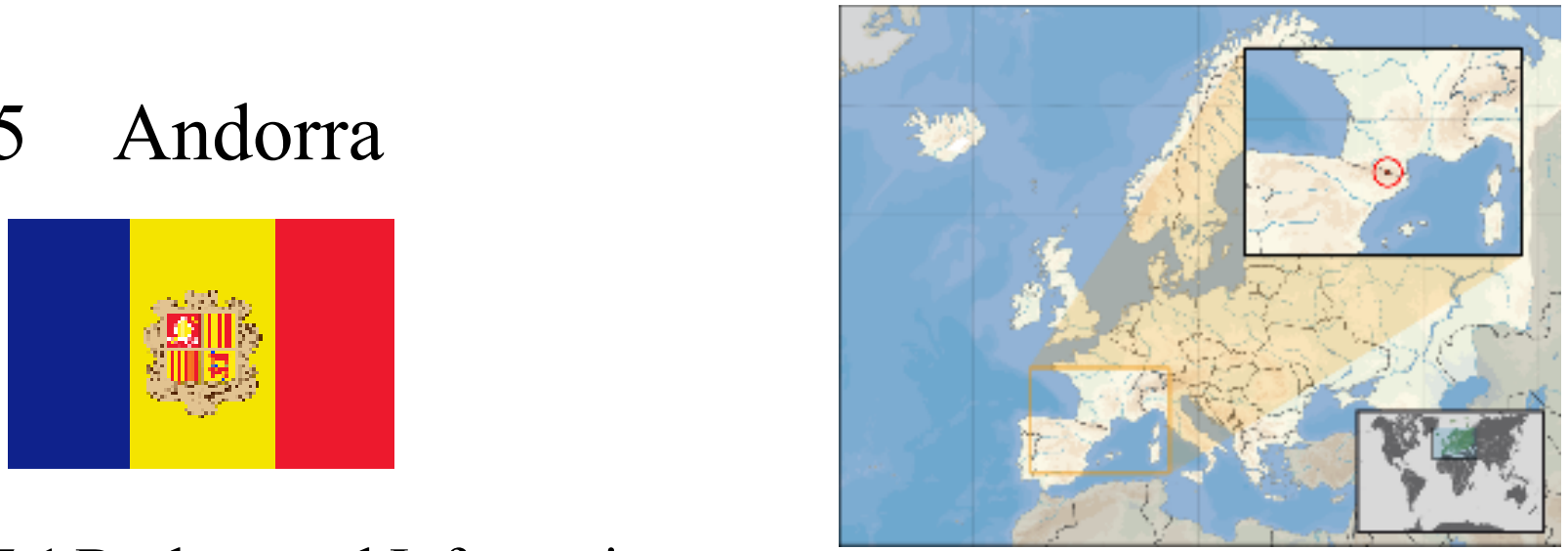

\subsection{Background Information}

\begin{tabular}{|l|l|}
\hline Population & 71,822 \\
\hline GDP (PPP) per capita US \$ 2005 & 38,800 \\
\hline Capital City & Andorra La Vella \\
\hline Date of Independence & 1278 \\
\hline
\end{tabular}

(Flag, map and information from wikipedia)

The information in this section is based primarily on an interview with a Spanish reporter who works for the local Andorran paper. The Andorran paper is a sister paper to the main Catalan paper in Spain. One and a half weeks before the interviews took place Andorra had a general election. One of the issues that divided the two leading parties was the nature of the relationship with the EU. The winners of the April $26^{\text {th }}$ Election were the Social Democratic Party of Andorra who argued for a closer relationship with the EU, with the outgoing governing party of the Liberal Party of Andorra being more sceptical about a closer relationship with the EU. This said both parties recognised the need to change the relationship as Andorra is subject to a punitive tax regime on exports to France and Spain, but differed in their opinion on how fast such a change should take place. The nature of the EU relationship was not the main focus of the electoral campaign but in comparison to recent years the issue was given a more prominent place in the importance in both parties' campaigns. Historically the main issue at the election was the problem of traffic management in the crowded coprincipality; however, recent road improvements have pushed this down the agenda. The most dominant issue at this election was the question of social security payments for unemployment. Andorra currently has a very limited system of social security payments for up to 3 months. It is also worth noting that the electoral system of Andorra is only open to citizens. Approximately 20\% of Andorra's long term resident population are citizens, the rest are migrants who generally reside in Andorra on a long term basis. This lack of enfranchisement skews the political debate in a more nationalistic and parochial direction. 


\subsection{Formal Relationship with the EU}

Andorra is not a member of the EU, nor has it ever applied for membership or indicated officially that it would apply for membership of the EU. The relationships of the EU and Andorra are based on the 'Agreement between the European Economic Community and the Principality of Andorra'. This treaty outlines the details of the customs union between Andorra and the EEC, and which products are exempted from the customs agreement. In addition the treaty has rules governing the definition of origins of products. The goods that are covered as part of the customs union are manufactured goods where Andorra is effectively treated as a member state, while in non-manufactured goods Andorra is treated as being a non member state (Commission $2004 \& 2005$ ).

Subsequent to the exchange of letters that concluded the customs union, Andorra and the EU have signed a Co-operation agreement that covers, 'environment, communications, information, culture, transport, regional and cross-border cooperation, and social issues'. Following this an agreement on Taxation and Savings was concluded, though Andorra has not yet been removed from the OECD list of uncooperative tax havens.

\subsection{Informal Relationship with the EU}

The information in this section is based on an interview with the Andorran ambassador who is accredited to the EU. In her view, the informal relationship between the EU and Andorra is not well developed. The main focus of the interview was on the lack of contact between Andorra and the EU, the need for Andorra to act as a lobby group with the EU institutions and the failure to capitalise on the opportunities presented in the co-operation agreement between Andorra and the EU.

The EU does not seek to contact Andorra when issues that will have an effect on Andorra are discussed. Andorra's relations are not in the form of a special partnership and all contacts are on a bilateral level with Andorra receiving little special attention or being consulted on policy that would have an effect on the coprincipality. The relationship between the EU and Andorra can be characterised as being one of two neighbours, though it must always be borne in mind that the neighbours are not of equal size or importance to each other. Andorra needs a good relationship with the EU, the EU does not with Andorra.

The Ambassador described how Andorra seeks to lobby the EU; Andorra acts like any lobbying party and has to find figures to influence in the European Institutions. The commission and the Member States form the main focus of 
Andorran lobbying, especially France and Spain due to the historical ties between the two states and Andorra. In addition, the Ambassador described how a member of the European Parliament likes to describe himself as, 'the member of parliament for Andorra', though in her opinion this was not always the case; it should be noted however that they embassy did enjoy working with him on many issues. The question of how successful Andorra is as a lobbying body was difficult to quantify since the ambassador felt that overall there was good progress in issues of contention but that it was difficult to give a list of concrete examples of how and where Andorra had succeeded solely through a lobby effort.

The Ambassador felt that despite the agreement between the EU and Andorra there was not a large amount of progress in any of the possible areas for cooperation, however she was of the opinion that with time this will change. Andorra has embarked on an economic development programme for the next decade to help diversify the economy; this programme includes making more use of the co-operation agreement with the EU and perhaps changing the nature of the relationship with the EU (Emerson 2007). It remains to be seen what the new government of Andorra will do in respect to the EU question in the state but it is likely they will seek a closer form of co-operation in the long run.

\subsection{National Discourse}

The economic theme of analysis was very strong in the Andorran discourse. Almost all the interviewees made comments about this aspect. The economic theme was neither presented as being entirely and argument for or against seeking a closer relationship with the European Union. Very often the status of Andorra as a Tax Haven was presented as a positive benefit of Andorra not being in the EU, however on occasion this was presented as being a barrier to closer integration with the rest of Europe and thus as a negative thing. In addition to low income taxation, low VAT rates were seen as being a benefit to not being part of the EU, though the interviewees who thought a closer relationship with the EU was desirable also thought there would have to be changed to these to allow for more integration. These aspects of financial independence were often cited as being one of the unique things about Andorra and all the interviewees felt that Andorra needed to keep some degree of uniqueness. In contrast to this positive view of economic uniqueness an example of the view that Andorra suffers from economic isolationism can be seen in the view of one long term Andorra resident who said that the Andorran economy was, 'too closed for new investment, we can never grow unless new things can start here'. She specifically cited the need for new business ventures to seek and Andorran partner to be allowed to establish themselves in Andorra. 
The other main economic focus of the interviewees was that a closer relationship with the EU would lead to a better social security benefits system. This reflects the main preoccupation of the recent election campaign and gives an insight into how the Europeanization of Andorra is represented in the discourse as being a move towards a less Liberal model and more social welfare state model.

Security was mentioned as reason for not being in the EU by several interviewees, there was a feeling that a lack of integration into the global economy and global politics protected Andorra from physical threats, one interviewee said, 'we are safer than France of Spain and joining the EU might change that.' The feeling that Andorra can 'fly under the radar' of the world appeared in several of the interviews and similar to the economic uniqueness of Andorra was not always characterised as a positive or a negative thing.

The idea of not being noticed is linked to the identity dimension of the Andorran discourse. All the interviews presented a view point that Andorra was unique and that the Andorran way of life should be preserved to some degree. An aspect of keeping the Andorran way of life was to do what the rest of the world wanted to prevent foreign interference, or to avoid notice by the rest of the world. One man said that, 'Andorra is expected to keep out of the news, if we make the news abroad it is bad news for us'. There was in balance to this a feeling that Andorra could not continue to be so isolated and that help was needed from outside to help maintain the way of life and that this would lead to having to compromise some of Andorra's uniqueness but that this was worth the cost. There was a noticeable lack of consistency in people's views about how Andorra should proceed on the path to closer integration with the EU. Many people felt unsure about what the options for Andorra were because of the small size of the state, however many felt that there would need to be a change.

Size is an additional aspect of the discourse that falls outside the analytical frame. Size was a common dimension of the discourse in Andorra. Many of the interviewees felt that Andorra was too small to become a full member of the EU, or that any attempt to do so would change Andorra too much because of the state's small size. Equally there was a very strong discourse of Andorra's vulnerability being its size and its dependence on foreign sources of economic growth, 'we need to co-operate on changing from being a tax haven, so that we can get the help we need to grow, we are too small to go on our own.'

\subsection{Conclusions}

The analysis of the Andorran discourse points to the dominance of economic arguments. However, these arguments do not consistently point in one direction; towards or away from integration with the EU. The lack of clarity in the discourse can be assumed to reflect the lack of attention Andorran politics has paid to the 
EU question in recent years. It will be interesting to see if the Andorra $2020^{3}$ strategy (Emerson 2007) and the election of the Social Democratic Party with an explicitly integrationist stand point changes this dynamic. It is perhaps also interesting to note at this point that the majority of interviewees are already EU nationals and thus many of the practical downsides to not being and EU national are not apparent to them, while the drawbacks of working outside the EU are more obvious. Andorra is the only case in the sample of this study where the interviewees may not be able to fully access the 'national discourse' so the conclusions drawn here should be tempered with this in mind.

The Security theme arose in Andorra and was explicitly pointed too by about a quarter of all interviewees. The strong feeling was that being outside the EU was a source of security to Andorra. When questioned those that mentioned security gave vague answers of France and Spain being more subject to terrorism or attack than Andorra. The view that EU membership has increased this risk shows a tendency towards scepticism of the benefits of EU membership for Andorra. The position of those that regarded EU integration as a potential security threat involved no comment on the presence of separatist regions or of a role in global affairs neither of which Andorra would have were it closer to the EU or not.

The identity descriptions of the uniqueness of Andorra's identity were primarily financially based. The reasons for this are probably many fold but include the predominance of foreign born residents who do not identify with Andorra for emotional reasons but are resident for practical reasons of work or tax convenience. In addition Andorrans share a large amount of culture with their Catalan neighbours in France and Spain and much of the nation's cultural resources are drawn from Barcelona; for example the main national paper is a supplement to the Barcelona based Catalan El Periodicó. The inability of most interviewees to define what is unique about Andorra beyond its financial provisions also points to the otherness of the EU. The financial differences and social security differences were always given in contrast to how EU states behave. This otherness is part of the identity of Andorra thus closer integration with the EU project may threaten the otherness of Andorra and thus Andorran identity.

The discourse of size is particularly relevant since the Andorran government's own Andorra 2020 plan acknowledges that it is unlikely Andorra will ever be a full member of the EU because of the size disparity. Though it does note that there is no formal reason Andorra can not join since the treaties say that, 'all European states' may apply for EU membership but the document views such a position as unlikely since the EU is unwilling to see this situation. Thus it discusses practical

\footnotetext{
${ }^{3}$ The Andorra 2020 strategy seeks to revitalise the Andorra Economy through diversification away from tax based competition. Part of this strategy includes potentially seeking some sort of associate membership of the EU or perhaps membership of the EEA. The initial steps recommended to achieve this are for Andorra to prepare itself as a reliable partner for the EU by unilaterally moving towards EU norms, which is what the Social Democratic Party have espoused in campaign literature.
} 
solutions to co-principality's problem. The most likely solution being some sort of Associate membership not yet existing, or to follow the 'Liechtenstein model' and seek membership of the EEA (Emerson 2007). The size discourse has entered into the 'national discourse' as many of those asked felt that Andorra was too small to enter the EU and saw this as either a reason to stay away from further integration or too find an inventive solution to the 'problem' of Andorran size. 


\section{Iceland}

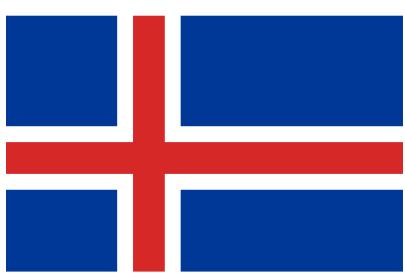

\subsection{Background Information}

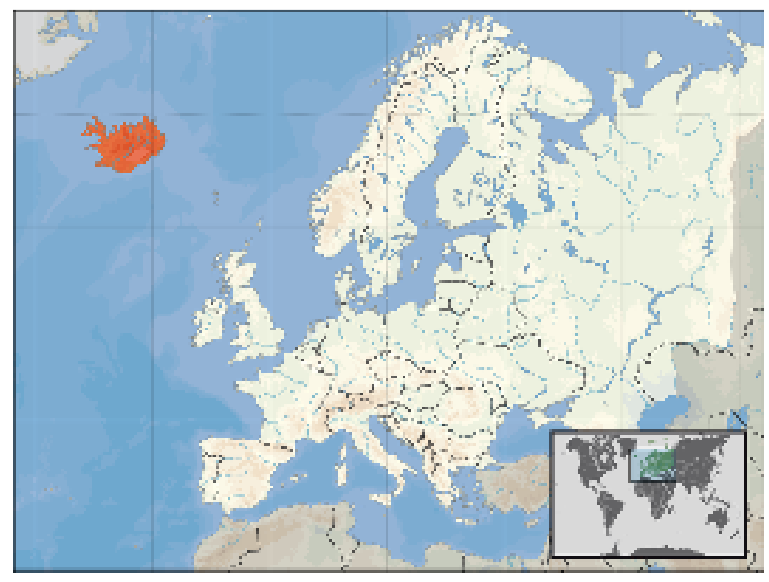

\begin{tabular}{|l|l|}
\hline Population & 319,756 \\
\hline GDP (PPP) per capita US \$ 2008 & 40,024 \\
\hline Capital City & Reykjavík \\
\hline Date of Independence & 1944 \\
\hline
\end{tabular}

(Flag, map and information from wikipedia)

To fully understand the data from Iceland it is important to consider the situation it was gathered in. Iceland suffered very badly from the Economic collapse of 2008, and in 2009 following weeks of protest the Icelandic government became the first in the world to fall as a result of the crisis. A temporary, minority, centre left coalition was formed and the research took place two weeks before the elections that were to replace this government. Throughout the crisis academics, the media and politicians discussed the role being outside the EU played during the crisis and the issue of the Euro was particularly important in the debate. Iceland had five political parties in the previous parliament; the pre crisis coalition consisted of the two largest parties; the conservative Independence Party and the centre left Social Democratic Alliance. The opposition was lead by the left wing Left Green Party; the other two parties were the centrist Progressive Party and the small right wing Liberal Party. The temporary government was formed of the Social Democratic Alliance and the Left Green Party with support of the Progressive Party in votes of confidence. The parties have tended to be Eurosceptic with only the Social Democratic Alliance supporting membership of the EU and most of the other parties adopting a wait and see position, though the Independence party have always erred on the side of scepticism, while during the crisis the Progressive Party became pro-EU membership. The Left Greens have a strong opposition to EU membership, but have in preparation for forming a government after the April $25^{\text {th }}$ election amended their position to allow for a referendum on starting negotiations with the EU about membership. All parties agree that any accession to the EU must be subject to a referendum. 


\subsection{Formal Relationship with the EU}

Iceland's formal relationship with the European Union is through the European Free Trade Agreement (EFTA). The EFTA gives Norway, Iceland and Liechtenstein access to the Common Market and to some EU programmes without becoming part of the EU. The EFTA states have accepted the entire Aquis Communitaire in relation to the common market and have accepted all future legislation (Commission 2009). In effect this means the four freedoms have been extended to the EFTA states. In addition Iceland has decided to take part in some other areas of co-operation with the EU outside of the common market, for example, Iceland is part of the Schengen area and takes full part in the Schengen COREPER and pays a contribution to and takes part in programmes such as Erasmus. Under EFTA Iceland has a right to take part in the decision making process with the EU however, it does not have a right to vote. As has been noted in much literature about the council, voting is very rare so this in effect does not mean that Iceland is at a too significant disadvantage (Elgström \& Jönsson 2000, 700).

\subsection{Informal Relationship with the EU}

Outside of the formal relationship with the EU the study has undertaken to find out about Iceland's informal relationship with the EU. The data here is based on an interview with a member of staff in the Icelandic mission to the EU. The main themes of this interview covered areas such as the changing nature of the mission to being a more lobby based activity, the disadvantages to not being fully integrated into the formal structures of the EU and the need to follow the EU decision making progress.

The need for the Icelandic Mission to lobby the institutions of the EU was commented on in a lot of detail. The extension of Co-Decision has meant that more often decisions that will affect Iceland are being made in an area where Iceland has no formal position. In addition the EFTA secretariat ensures that at the start of each presidency the EFTA states remind the incoming presidency of their presence in the European field. This sort of lobbying can be very successful, for example the French Presidency invited the EFTA states to attend all the council working groups that had a relevance to EFTA. This also highlights the capacity of Iceland to attend all meetings; however, it is not unheard of for Iceland to be unable to attend through lack of staff in Brussels. In addition to this EFTA based lobbying Iceland works with its Nordic partners at many levels. There are regular lunches for the Nordic Ambassadors from states within and without the EU. Other linkages are made on an issue basis, for example, Iceland has been working with Malta to find a solution to including flight emissions in Carbon Dioxide 
allowances as both states are highly dependent on air travel for their communications.

The second theme of not being fully integrated into the EU decision making process was highlighted because of the need for Iceland to get its voice heard. Iceland makes a contribution to the EU particularly to the Cohesion funds and thus Iceland is particularly interested in influencing how the money is spent. In addition, as Iceland takes part in other EU programmes for example Erasmus or Science and Research funding programmes it is important for Iceland to be able to influence this process. The situation of Icelandic officials having to explain to their European Colleagues that they had a right to be in the room for many of these discussions was commented upon during the interview. Officially Iceland's only point of contact to the EU is with the Commission, but as has previously been noted Iceland seeks to act as a lobbyist to affect other parts of the EU.

The third theme is linked to the other two. As Iceland is not part of the EU it does not receive notification of changes in the EU from the commission. The EFTA secretariat closely monitors the EU's activities and informs the EFTA states, and Iceland follows the discussions on areas that are deemed to be of important national interest. An example of this can be seen in the common fisheries policy. Iceland is not part of this policy but is concerned about the outcomes of these negotiations as they will impact a very important economic sector in Iceland. Iceland now has a national expert who is funded by the Icelandic government but works wholly within the Commission who is advising on this policy. This expert is on paper an employee of the European Union, however everyone involved with the process is aware of his 'two hatted' nature.

\subsection{National Discourse}

The interviews in Iceland with members of the public revealed a set of issues that the debate around the EU balances. These issues are Fisheries, State Capacity, the Euro, the Crisis and Democracy.

The first issue highlighted by almost all interviewees was fisheries. Historically fisheries have been the dominant sector of the Icelandic economy, and today are still highly influential. The current arrangement between Iceland and the EU leaves fisheries and agriculture out, thus these are the biggest areas that will have to be dealt with in any potential EU application. Many interviewees made statements similar to one woman who said, 'we need the EU and the Euro, but, we can not afford to give them our fish in return'. The fisheries argument is usually presented as being part of two of the themes in the analytical framework. Firstly it falls under the theme of economy. The economic importance of fisheries to Iceland means that any debate about the EU includes a consideration of the effect the Common Fisheries Policy will have on Iceland. The second aspect is that of 
Identity. Iceland is a young nation that gained full self governance in 1944. However, many Icelanders perceive that it was not until the full control over the exclusive economic zone was reached in 1974 that real independence was achieved (Ingebritsen 2006 79-83). The feeling of, 'we can not give them our fish', reflects this fear of a loss of control of a vital natural resource.

Several interviewees discussed the capacity of Iceland to react to the demands of the EU. Here there was no consensus of if Iceland has the capacity of not, however it was clearly a point of discussion. Comments ranged from, ' As Ólafur [the President of Iceland] says, we are too small, we just can't get to all the meetings in Brussels and Paris and so on, we can not do it' to, 'Other small countries can do it, why would Iceland be different. If Malta can, so can we, I mean we are the same size, right?' The capacity dimension does not fit entirely into any of the categories created before the analysis, capacity as an aspect of size can be fitted into the identity dimension since this factor is part of the self identity of the state.

The Euro and the Crisis can be analysed together since in many statements they are linked. A good example is from a man who said, 'we had a choice before but now we need the Euro to get out of this kreppa [the economic crisis].' The debate in Iceland currently revolves around if being in the EU would have protected Iceland from this crisis and if an application should be made to protect Iceland from any future crisis. This highly economically framed debate comes in part from the political class who shape the debate in economic terms, good examples of this can be seen in the quotes from a young man and woman who were interviewed together:

A: 'I have always voted for the Independents, but this time I am not sure. I just don't believe them any more...'

B: 'I agree, they have always said the EU would hurt us, but now I am saying it will be better, we should join; the social democrats were right and are still saying it...'

A: 'It is not like I will just vote on Europe, but since they all say it will cost us or help us, well, I feel like I just have to say that I can't believe it will cost us like they have said.'

The political debate on the EU has been a cost/benefit analysis, which is linked to the issue specific debate on fisheries. It is obvious that these themes of the Euro and the Crisis fit into the economic debate.

Democracy or a lack of democracy in the EU was the final dominant theme in the discourse in Iceland. Several of the interviewees commented that Iceland would be less democratic if they joined the EU. However, it was not questioned that EFTA was democratic. An external analysis of this point would lead the reader to consider that the EFTA was more likely to be seen as less democratic, however 
the perception of EFTA is that decision making has not really moved from Reykjavík to Brussels.

\subsection{Conclusions}

In analysing the Icelandic discourse about the EU we find that the themes of Economics and Identity are very important. The security theme is not mentioned, this probably reflects Iceland's long history of peace, and the protection offered by physical isolation. It may be worth noting that Iceland as an entirely demilitarised nation relies on NATO for territorial defence and though the presence of foreign troops on Icelandic soil can at times still be controversial, however the EU is not seen as being a purveyor of security and therefore this issue is neutralised. The importance of identity is highlighted in the interviews. Identity is often seen through the central role of fisheries in Icelandic society and in one case the unique environment of Iceland. Identity questions remain highly unstable in Iceland as a result of the financial crisis and the on going debates around what should be the response. A final factor of the perceptions of size of the state has been noticed. Size is a more complex issue than just the factor of Identity and it may be beneficial to consider that size should be an independent analytical factor from the other categories. This point will be revisited in the final conclusion of this thesis.

What will be interesting to see is if Iceland resolves to apply for EU membership or not how the size factor is weighed and if debate about the similar sized states of Malta and Luxembourg is given much importance. Iceland provides a unique case in this study of a state which a highly active EU debate on membership and thus the impacts of the discourse on membership potentials are most obvious. The final analysis will consider these differing discourses and analysis how they have affected each of the states approaches to the EU. 


\section{Luxembourg}
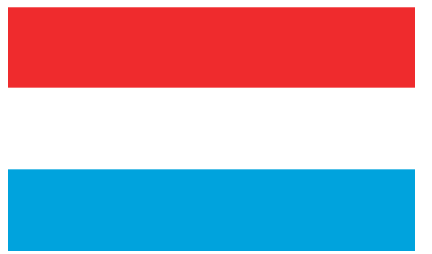

\subsection{Background Information}
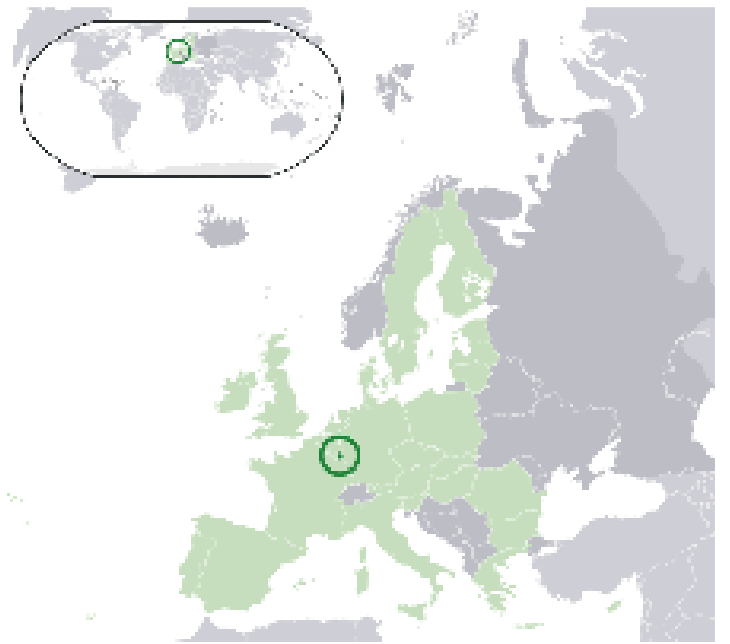

\begin{tabular}{|l|l|}
\hline Population & 493,500 \\
\hline GDP (PPP) per capita US \$ 2009 & 78,108 \\
\hline Capital City & Luxembourg \\
\hline Date of Independence & 1890 \\
\hline
\end{tabular}

(Flag, map and information from wikipedia)

The interviews in Luxembourg took place shortly after global media coverage of Luxembourg's tax laws. President Obama had recently called for all 'tax havens' to co-operate with international efforts to end the practise of tax havens and there had been talk that Luxembourg would be placed on the OECD list of uncooperative tax havens. While this did not happen, Luxembourg, Belgium and Austria, along with other non EU states, were forced to make some changes to their tax laws, thus the issue was fresh in many people's minds during the interviews. It was felt by the governments of the three EU states that they had been unfairly targeted and along with the Swiss they had been particularly vocal in their opposition to the measures.

\subsection{Formal Relationship with the EU}

Luxembourg is a full member of the EU; as one of the founding states of the European Coal and Steal Community and the European Atomic Energy Community Luxembourg has always been involved in the European Integration Project. Before the advent of the European Communities Luxembourg was a participant in the Benelux union with its neighbours Belgium and the Netherlands. It is often argued that Luxembourg's small size and position between the great powers on the continent has led Luxembourg to seek protection in terms of trade security and physical security from these types of unions with the powers that surround them (Laurent 1982). As a full member of the EU Luxembourg has all the formal voting rights and is formally an equal member of the EU with the other member states. 


\subsection{Informal Relationship with the EU}

The informal Relationship of Luxembourg with the EU is slightly different to the other states under consideration in this thesis since Luxembourg is a full member of the EU. While Luxembourg is on paper an equal participant in the EU, the practises and common behaviour of Luxembourg demonstrate an awareness of the state of being of a different order of magnitude when it comes to size. Luxembourg is less likely to use the veto than the larger state; however, since the council normally decided by unanimity it has in practical terms a limited effect on Luxembourg (Matilla and Lane 2001).

\subsection{National Discourse}

The interviews in Luxembourg uncovered an unrelentingly positive discourse about the EU. None of the interviewees believed that Luxembourg would be better off by distancing itself from the EU or even leaving the EU, and many of the interviewees felt that Luxembourg would benefit from a closer integration with the EU. Not all interviewees were willing to say that Luxembourg would benefit from closer integration there was, however a very strong pattern of being pro-integration and criticising enlargement of the EU from a perspective of enlargement hindering deeper EU integration.

The strongest of the three analytical themes in the discourse in Luxembourg is that of economics. As noted above the Luxembourgian interviewees were all positive about EU membership and the most common reason given for being positive was that membership of the EU was good for Luxembourg's economy. A good example can be found in the quote from a young woman who said, 'we are more strong, in economy I mean, when we are together with Europe. We are stronger in economy that way.' The interviewees were able to give concrete examples when asked of how the EU benefited Luxembourg in economic terms, these included access to a wider market, access to a larger pool of labour than the state could otherwise support, the ability of Luxembourg to easily provide banking abroad, the effect of the common market of lowering costs in Luxembourg and the stability provided by the Euro. The long list of economic positives that most Luxembourgians generate when asked gives evidence of the 'rational' argument made in Luxembourg in favour of EU membership. Most of the individuals interviewed would not experience all of these positives in their daily life, however they perceive them as being a national benefit and thus accept these explanations for Luxembourg's EU membership. The economic discourse in Luxembourg is well developed across the whole of the society and is seen as the basis for continued EU membership. 
The security aspect of the analytical frame was explicitly mentioned by two of the interviewees. Both of the interviewees who mentioned the security dimension did so in historical terms as having been a key reason for Luxembourg to want to be in the EU. Both of those who mentioned the security rationale in this way were older people and this may reflect an older discourse, or a different set of priorities of people with a more lived experience of war in Western Europe. However, having said that only these two explicitly mentioned security, the security theme was implied in many of the other answers, 'Socially we are stronger with the EU'. This theme came up several times and when questioned further as to what being stronger socially meant the interviewees argued in terms of solidarity. Most often they took an example from the financial crisis of how the other member states helped look after the more vulnerable ones. It can be argued that security themes are implicit in this since the idea of solidarity in the face of a crisis can be easily extended into the ideas of solidarity in the face of a physical crisis, however it is worth noting that once again solidarity was framed in economic terms. This, once again, indicated the dominance of the economic theme of the discourse within Luxembourg.

The theme of Identity was much less apparent in Luxembourg, while many of the interviewees felt European, a pattern that is common in Luxembourg (Eurobaromater 2000). This was not an over riding part of the discourse. What was emphasised by most of the younger interviewees is, 'this is how it has always been, you have to understand for us it is normal.' The EU is not seen to be something unnatural placed upon Luxembourg but it is something that is underlying the fabric of Luxembourgian society. Many of the interviewees linked this idea of the 'naturalness' of EU membership with a part of the discourse that is outside of the analytical framework. One of the most common answers within Luxembourg was the discourse of 'practicality'; this discourse includes an argument of EU membership making daily life easier. The discourse of 'practicality' in Luxembourg is very strong appearing in most of the interviews. Examples of how EU membership was practical ranged from the Euro to the Schengen agreement. The discourse included a very strong 'rational' argument in terms of day to day life being easier because of EU membership and this being of benefit to the individuals who were interviewed. In other words, it was a felt benefit not a perceived general benefit as many of the economic ones described earlier are.

A final theme of size was prominent in the discourse in Luxembourg. As before, size can be seen to be part of the identity of the citizens of the state. There was in the discourse a strong theme of the EU allowing Luxembourg to act on a larger stage than would otherwise be possible for such a small state. There were in several interviews concerns expressed about enlargement as it would dilute Luxembourg's relative power in the EU, and that it would reduce the ability of the EU to harmonise, which was seen as an unquestioned benefit for Luxembourg. There were no concerns about Luxembourg's ability to be heard on the European 
stage, or for the state to have the capacity to fulfil its obligations as an EU member; this is probably not surprising given its many years of membership. The discourse of 'size' in Luxembourg is one of Luxembourg benefiting from EU membership as it gives Luxembourg a voice on the global stage that the state would never have otherwise, because of its size.

\subsection{Conclusions}

The case of Luxembourg is one of a state that has been integrated into the EU system for a very long time. The discourse in Luxembourg reflects this long standing level of integration into the EU system with membership being considered natural by many of the interviewees. The economic theme of the analysis proved to be the strongest despite the back drop of the global 'crack down' on tax havens that was perceived to be a disadvantage to Luxembourg. It is telling that despite this negative effect for Luxembourg all the interviewees viewed membership as being 'worth the costs'. This economic strand of the discourse was the strongest of the three analytical themes, security was mentioned as being an important theme by several of the interviewees; the third theme of identity was not once mentioned by any of the interviewees in any explicit form and was only obliquely referred to in terms of being European. The important themes in the discourse that do not form part of the analytical framework are those of practicality and size. The security and practicality themes both reflect the dominance of the economic theme with this aspect being emphasised even in reference to security and most of the examples of practicality were framed in economic terms. The discourse of size was not as explicitly economic; this discourse was framed in terms of influence. The power dimension of this discourse is missing from the analytical framework and may form an important theme in the final analysis. 


\section{8 Åland}
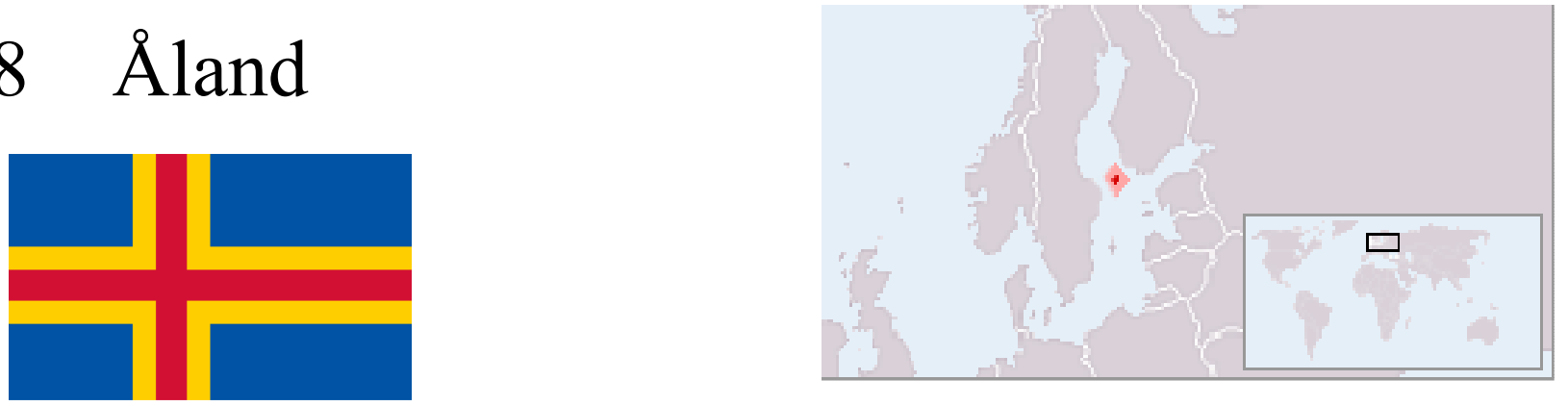

\subsection{Background Information}

\begin{tabular}{|l|l|}
\hline Population & 27,210 \\
\hline GDP (PPP) per capita US \$ 2007 & 36,327 \\
\hline Capital City & Mariehamn \\
\hline Date of Independence & N/A \\
\hline
\end{tabular}

(Flag, map and information from wikipedia)

The interviews in Åland took place during a period of little debate about the EU in either Finland of Åland. The debate over membership has subsided and the Lisbon Treaty was ratified fairly easily in Finland. The issue of particular importance in relation to the EU that has been prominent in the discussions within Åland is that of hunting of sea birds which has been restricted by the enforcement of the Birds Directive. The commission took enforcement action against Finland to force the end of the hunting season before the migration of certain species of birds (Commission 2006).

\subsection{Formal Relationship with the EU}

Åland is an autonomous part of Finland, and joined the EU with Finland in 1995. The islands had a separate referendum to the rest of Finland and decided to join along with the rest of the country. Most EU Law applies in Åland; however it is outside the VAT area of the EU, which means that duty free still exists in Åland which gives significant tourism revenue. In addition Åland also does not apply the common rules on turnover tax and has restrictions to the free movement of persons and services and restrictions on the holding of real estate. The special status of Åland within Finland was recognised in the Finnish accession treaty and thus Åland retains its unique status within the EU (Council Directive 2006, Official Journal of the EU 1995) 


\subsection{Informal Relationship with the EU}

The data here is based on an interview with a member of the Ålandish government. The main themes from the interview were the difficulty of being understood by the EU as a unique region, the need for better representation of the regions and the need for understanding by the EU of the diversity of the Union.

The interview began with a discussion of Åland's strategy for influencing EU decisions. The view of the official being interviewed was that the first step for Åland in seeking influence was Helsinki. Allandish politicians as part of the Swedish minority in Finland are an established presence on the political scene and are well respected within Finish politics. Generally speaking the arrangement between Åland and Finland work very well together and the Helsinki government is a good advocate of Allandish issues. However, there is a problem of energy, the Finish government has a broader range of issues to focus upon and can not always devote the time and energy to Alland that the people of Alland would like. Therefore, the official interviewed felt it was important for Åland to have a stronger voice in Brussels. In the Finnish permanent representation, there are officials who work for Åland and take care of Ålandish issues, however the parliament lacks representation for Åland. The official who gave this interview felt very strongly that it was important for Åland to have a reserved seat in the European Parliament to give Åland a voice in this important body.

The reason Åland needs a more powerful voice is the lack of understanding that the EU has about diverse rejoins in the EU. The best example the official interviewed could think of was the Birds Directive. The official agreed that regulation of the annual bird hunt was required but it should be done in a way that is sensitive to local needs. Regulation not banning would be far more appropriate. The lack of understanding in the EU means that local issues like this can be misunderstood. The committee of the regions provides a small voice for places like Åland, however its consultative only role limits its influence and thus a stronger voice for the regions in the Union would be of great benefit for Åland. Åland is represented in the committee but it is not the main focus of Ålandish efforts to influence the EU.

The official did not wish to comment in detail about relationships with other states, but was happy to say that Åland co-operates well with other regions around the Baltic, and would if it was 'appropriate' look to co-operate with other national governments. 


\subsection{National Discourse}

The research in Åland found that the main areas of discourse were the euro, hunting of sea birds and the size and uniqueness of Åland.

The economic discourse was the strongest of the three analytical themes; though it can difficult to draw a line between a discourse of economics and practicality in the case of Alland. The economic aspect of the discourse in Åland is centred on the Euro. The common European Currency was seen as being a positive benefit to Aland by all the interviewees who expressed an opinion. The main reasons given are summarised in the following two quotes, 'the Euro has really protected us, in this crisis' and 'it is so good having the money since going abroad is easy'. The second comment was followed by, 'though Sweden doesn't and that is not good'. Thus the blending of an economic and practicality discourse can be seen. A small number of the interviewees expressed an opinion that the tax arrangement for Alland was important in the relationship with the EU, this was always expressed as a feeling that the EU was not good, but it was acceptable as long as this was left alone. The lack of the tax arrangements being mentioned by most other interviewees in all probability reflects the fact that there are no serious discussions about changing this arrangement, however were it threatened it would probably become a much larger feature in the discourse.

The security theme was not mentioned by any of the interviewees. This is most likely because Åland has existed in a calm security environment for many years and there is no perceived threat by the inhabitants and thus there is not a feeling that the EU changes the security environment of the islands.

The identity aspect of the analytical framework was not referred to explicitly in the interviews, however there were strong aspects of this in the discourse about Åland's uniqueness. The annual bird hunt in Åland has been affected by an EU ban on hunting out of season, as described in the background information. This was perceived as being a very negative effect of EU membership and was described as having, 'made a lot of people very angry'. This was further expanded on by several interviewees as only one example of the EU being unable to understand and respond to the needs of small, unique regions, other examples being given in agricultural policy. This uniqueness was often coupled with the problem of size, one interviewee said, 'we are a small region and struggle to make Finland listen, and then Finland is small in the EU', this was seen by many as being a problem of EU membership, but it should be noted that none of the interviewees, including one who prefaced her answers with the caveat that she has opposed EU membership from the start, felt that Åland should leave the EU.

The discourse about continued membership of the EU was positive. The feeling of most interviewees was that no change in relationship with the EU was possible or even desirable. The quote of one man sums up a very common position in Åland, 
'nothing really changed much other than the money when we joined, so it would not make sense to change anything now.' The feeling that life was good how it was and leaving the EU could risk that was very dominant. A second more prointegrationist discourse also existed along side this and about a quarter of the interviewees either said they would seek a closer relationship with the EU, or would like to see changes that were pro-integrationist. One interviewee said she was disappointed with the failure of the EU to integrate closer on issues, when asked to give examples she cited immigration and the currency. While other interviewees did not give concrete examples several of them talked about seeking closer co-operation amongst EU states.

The final point to note about the national discourse in Aland is the lack of a strong discourse; many of the interviewees were hesitant to express clear ideas or answers due to a lack of knowledge or strong opinions. Several of the interviewees said they were unable to answer the question because they did not know or had never thought about it. The lack of a strong discourse tells us that within Alland there is not currently a highly active debate about the EU, the current relationship is not highly politicised or debated within society. The discourse mostly allows people to feel that today's relationship is good at best or not harmful at worst and thus should be maintained.

\subsection{Conclusions}

Åland gives a good example of where the analytical frame work does not explain much of the discourse. The lack of any strong and clear debate in Aland means that much of the discourse is unfocused and latches onto individual decisions or actions of the EU as a centre point for discussion, in this case the hunting ban. It is important to note that despite this negative centre to the discourse it is clear that there is a generally positive feeling towards the EU in Åland, and that interviewees were either in favour of closer integration or of no real change in the status of Åland in relation to the EU.

The economic discourse remains the strongest of the three analytical themes as it is the most tangible to the people of Alland with the change from the Finnish Marka to the Euro, though as noted earlier it is difficult to separate this from a discourse of practicality in some instances.

The other most noticeable part of the discourse was that of lack of influence due to size. This in all probability reflects the position of Åland in being a minority community in Finland and seeking to influence Finland, thus the same problem is perceived as being relevant at an EU level. This size discourse can be put into the identity discourse since an aspect of self identity is being part of a small separate community. The case of hunting also highlights the identity aspect of the 
analytical frame since the negative perceptions of the EU arise when there is a direct conflict between Ålandish identity and EU membership.

The security aspect of the analysis was completely missing but as speculated earlier this probably reflects the relatively long period of stability Åland has enjoyed. The lack of this aspect of the analytical frame in Aland tells us that membership of the EU is not discussed in these terms in Åland. The lack of a strong discourse about EU membership is an interesting finding in itself. The lack of a clear set pattern of discourse for the population to analyse the relationship with the EU and the relatively high level of lack of knowledge or interest in the question tells us that membership of the EU is generally uncontroversial in Åland and the benefits of membership are generally accepted as a given in Åland even if they are not understood in concrete terms by much of the population. 


\section{Jersey}

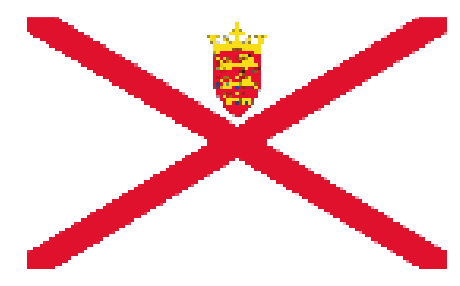

\subsection{Background Information}

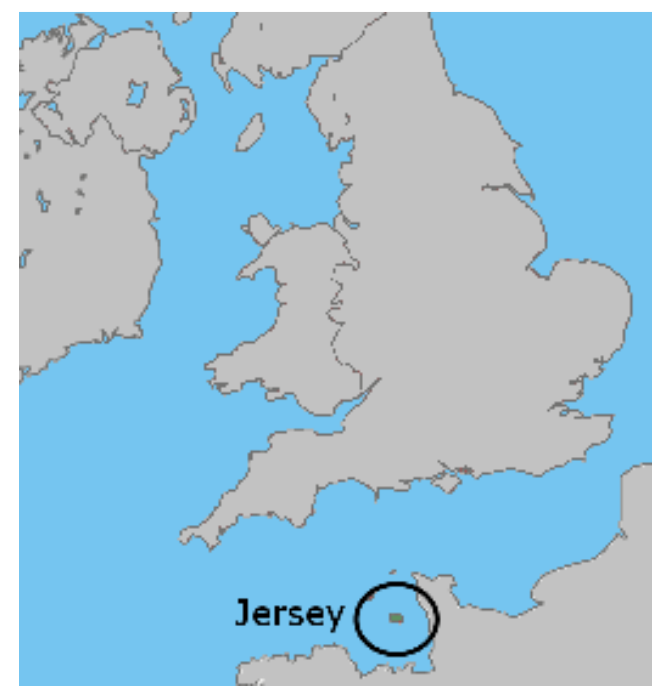

\begin{tabular}{|l|l|}
\hline Population & 91,626 \\
\hline GDP (PPP) per capita US \$ 2003 & 40,000 \\
\hline Capital City & St. Helier \\
\hline Date of Independence & N/A \\
\hline
\end{tabular}

(Flag, map and information from wikipedia)

Jersey has not had any serious discussion of EU membership at any point in recent history. The general view of the islands people and politicians has been that the island is economically and socially better off outside the EU. The most recent discussion that has come close to something like integration with the EU was last year when the islands parliament discussed moving Jersey onto the European Time Zone, the island currently uses the GMT time zone of the UK. This was rejected overwhelmingly by the islanders in a referendum for several reasons including longer working hours for the banks to fit with both Europe and the UK, and because it was deemed unnecessary for the island to bear the costs of the changes (Time and Date 2008).

\subsection{Formal Relationship with the EU}

Jersey is a crown dependency of the UK and as such has internal self governance. The States General of Jersey decided that Jersey would not join the EU with the UK in 1972. However, Jersey is still subject to some EU rules. Jersey forms part of the common market and thus applies much of this legislation but is not subject to VAT legislation and is not part of the Common Agricultural Policy. Jersey nationals are not UK citizens and thus do not have European Citizenship and the rights associated with this either in the UK or in the rest of the EU. Of the four freedoms only the freedom of goods applies in Jersey the other four freedoms are either limited or non existent to Jersey residents (States of Jersey 2009). 


\subsection{Informal Relationship with the EU}

The data in this section is based on an interview with a civil servant based in Jersey a high level of anonymity was requested due to the sensitive nature of the topic in the island's politics.

Jersey does not have a well developed bilateral relationship with the EU, the UK is primarily responsible for maintaining Jersey's international relations. However, in terms of the EU the UK is a member state and thus the relationship is complicated. The UK permanent representation in Brussels was considered to be a very poor protector of Jersey's interests since it was seen as being too EU friendly and not siding with Jersey on most issues. The government of Jersey instead often preferred when issues of great importance to Jersey are being debated in the EU to dispatch politicians and civil servants directly to Brussels and London to lobby on Jersey's behalf. The primary focus of the lobbying effort is usually initially in London to establish if the UK ministries will take a position that is friendly to Jersey's interests. If this is found to be the case the government of Jersey often does not feel the need to extend the lobbying mission to Brussels as the UK has an important voice that will be listened too which will be far more influential than any attempt Jersey can make on its own to influence the EU. Should London wish to take a position that does not fits with Jersey's own needs then the government of Jersey seeks to directly influence the commission of the EU by lobbying for exemptions for the state or for special considerations. Jersey's main approach is directly to the commission departments responsible for the proposed legislation. When asked about lobbying the parliament or member states the official interviewed expressed the opinion that while that is the official policy of Jersey it is not done. The official was of the opinion that some contact with parliamentarians from the UK was a possibility but that contacts with other member states were very unlikely and this explained to a large degree the failure of Jersey to have any influence when the UK holds a different position.

The official felt that the politician's 'distaste for a closer relationship with the EU' meant that they failed to take seriously, 'the threat to Jersey's powers that Brussels posed'. The official was arguing that the feeling of distance from the EU meant that many Jersey politicians did not seek to engage in the system and thus seek to protect Jersey's interests that can be affected by EU decisions.

\subsection{National Discourse}

Considering the three categories of the analytical frame work the category of security was not part of the discourse in Jersey at all. No statement from any of the interviews indicated that this was a concern for anyone on the island. This is 
probably explicable in terms of the long history of peace that Jersey has and the lack of any imminent physical threat. In addition as Jersey's own parliament does not deal with the island's security, this is provided by the UK, it is not an issue on the local political agenda.

The two factors that were a large part of the discourse in Jersey are the factors of economy and identity. The identity factor was much stronger than the economy factor and thus will be analysed first.

It must first be emphasised that none of the interviews were positive towards the idea of Jersey becoming a member of the EU and this often led to the interview being an exploration of the reasons why EU membership was perceived to be a bad thing. The single most common reason for believing that EU membership was a bad thing can be given in the commonly used phrase, 'Jersey is special'. Upon asking for this to be clarified the answers were never very specific including, 'people here are different, just different', 'we have our own special way, you know, our independence', 'were going well we don't have political problems' and 'we have our own identity'. This issue of identity is very clearly focused as the centre of the opposition to the EU.

As is evidenced in the above quotes the notion of Jersey being independent and somehow 'different' is a strong focus of opposition. Attempts to get clearer examples of how Jersey was 'different' almost all failed as most people were happy with the argument that people were just 'different'. The concrete examples given were that they used the Jersey pound and they would not want the Euro, only one interviewee mentioned the tax system, and a quote from one summed up the general opposition as, 'if we were subjected to a foreign power, everybody would get angry'.

The most telling comment came from one of the interviewees who gave the answer that she thought Jersey was better off out of the EU because they were independent. This was then followed with a comment delivered as a stage whisper, 'well I shouldn't say it, but we are not really independent at all'. When she was questioned why she shouldn't say it, she explained that people get 'angry' if you tell them they are not independent. She explained that in her view Jersey was just so small it could be ignored by the UK and be allowed to remain an anachronism in the EU system. She felt that Jersey was better off this way because it let their economy grow and let the island prosper and changing it might make things worse. When questioned again as to why Jersey was better off, the answer was that Jersey was, 'just a bit different too the Mainland [The UK]'. This example demonstrates the power of the discourse as despite the fact she does not believe Jersey is really independent she arrives at the same reasoning as those who do not question this aspect of the discourse, that Jersey is just different.

This also gives us our first real insight into the economic dimension of the discourse. While the economic dimension of the discourse is not highlighted by 
any of the individual interviews. This interview shows the basic assumption that underlies the discourse of independence. Jersey is currently very wealthy, as shown in the table at the start of this chapter. There is a strong feeling that changes in Jersey's position could imperil this wealth thus the natural human tendency to conservatism leads to an opposition to changes in the position. The other economic arguments given were predominantly symbolic in nature, for example the importance of the Jersey pound.

The other main theme of interest in the data from Jersey was the very low level of knowledge or interest in the EU. This can perhaps be best summed up by one respondent who agreed to be interviewed though before any questions had be asked said,

'I can tell you what people think, they don't want the EU and they don't want to know about the EU, like you [my accent makes it clear I am mainland British], we know we will be better off with out foreigners telling us how to run things'.

A majority of interviewees said that they didn't know about the EU before attempting to answer any questions and several interviewees could only answer that they did not know about the EU to any level to give an opinion. This contrasts strongly to all the other states where the population has had knowledge and opinions, be they positive or negative, about the EU. This reflects the lack of any debate within Jersey about joining or moving closer to the EU. In addition though as evidenced by the quote there is a lack of any desire to know about the EU. The discourse that Jersey is better off outside the EU is so dominant that it is not problematised at all within Jersey.

\subsection{Conclusions}

Jersey represents a very good example of the highly important role of Identity in understanding a states relationship with the EU. Membership of the EU is incompatible with the Jersey self identity as an 'independent' entity. The notion of independence is not well defined, but is clearly understood to not be possible to be mixed with membership of the EU. The discussion above speculates about the economic underpinnings of the identity issue, however it is too reductionist to argue that only economics can explain identity. Identity is a self standing reason for behaviour and while it does not fit into a 'rational' economic framework it can be as powerful an explanatory factor. In the case of Jersey while economic factors may be part of the understanding of the identity. It is probably more important to consider that identity and self perception of identity are in themselves powerful explanatory factors that have grown over time. 
The position of the Channel Islands in constitutional terms is unusual and this coupled with their geographical location, the comparative wealth to the UK and the different history will all form part of a greater sense of identity that is different to the UK and to their continental neighbours. Even though this identity is not clearly articulated in the interviews it does not mean that it is not strongly felt even if it is not well understood by those who feel it. 


\section{Conclusions}

\subsection{The Economic Discourse}

The first analytical theme discussed was that of economics. This theme sought to cast EU membership as being viewed in terms of the direct economic costs or benefits of membership or association with the EU. The theme was clearly seen in most of the discourses. Iceland had the clearest economic viewpoint as the nation had undergone massive economic turmoil and thus the debate was framed by this, Luxembourg, Alland and Andorra all show cases of how the economic argument is used as a rational underpinning for the relationship with the EU. The Jersey discourse did not make as explicit a reference to the economic implications of the arrangement with the EU, however the identity issues there were sometimes framed in terms of economic arguments.

The all pervasiveness of the economic discourse most likely represents the way politics works in western nations. Politicians are pressured to present arguments in terms of financial costs and gains for their constituents. Thus the arguments given for reasons to be integrated or not with the EU are given in financial terms. In addition it should be noted that the EU has been predominantly and economic project, thus it seems natural that the debate about the EU should be structured in terms of economics. It is also worth noting that Jersey as the only state where economics were not the main focus of the discourse is the only state where there was a clear majority against closer integration with the EU.

\subsection{The Security Discourse}

In contrast to the economic discourse, the security discourse was largely absent from this study. It was mentioned in Luxembourg by older interviewees and formed a part of the Andorran discourse but was otherwise absent. This lack of discussion of the security implications of the EU in the small states under study probably reflects the bias towards Western European states created by the selection criteria. The lack of any serious military threat in the West of Europe in recent history has led to a lack of discussion about security issues in these states. Often the security debate has become focused on the diffuse threat of terror which is associated with involvement in international politics. Size offers a shelter to the 
states under study as they are not expected to become involved in international politics to the same degree as larger states in Europe.

The other potential factor to consider is that the EU is not viewed as a purveyor of security in the states under study. If the EU is not seen as being relevant to the security debate it will not form part of the discourse in the states and thus not appear in the interviews.

The data from this study would suggest that security does not warrant a place in the main analytical framework, however it must be remembered that many of the small states that could have been included are from Eastern Europe or the Balkans. Had the study been undertaken using these states there is potential that security could have played a bigger role in the discourse. In addition, had the study been undertaken at a different time security could have played a bigger role. If we consider Malta's accession to the EU, security issues played a large part in the debate (Pace 2001, 199-289). Thus, the position of security as an analytical theme can be defended even if this sample gives the impression that overall security is not an important analytical tool.

\subsection{The Identity Discourse}

The identity discourse was more difficult to 'pin down' in most of the data sets. Jersey has a very clear discussion of identity, Åland and Iceland had explicit discussions of identity but these were not the main focus of the discourse, while Luxembourg and Andorra had more oblique references to identity in their discourses. The more nebulous nature of identity in the discourses probably represents the difficulty in most states of talking in explicitly identity based terms. It is of importance that Jersey is the only state where identity was the main focus of the discourse as the economic arguments were not entered into since the visceral dislike of the EU meant that it was so incompatible with the identity of the Jersey population that there could be no further discussion. The lack of a focus on identity in the other discourses probably represents the need for identity questions to be resolved to some degree before other debates can be started. This means that if a closer relationship with the EU is to be sought then it can only be examined in terms of security or economics once it is seen as compatible with national identity in some way. Luxembourg provides a useful counterpoint to this, the interviewees in Luxembourg were not happy to countenance a change in the relationship with the EU. For most interviewees the EU was seen as being a natural part of Luxembourgian identity. Thus, since a change in relationship violated the identity discourse within Luxembourg it was not possible or desirable to consider any change in relationship with the EU. 
The other states show a more moderate position where identity issues have been resolved to the degree that a discussion is possible but they are not set in either direction and thus changes can be contemplated but are not necessarily going to be compatible with identity discourses but other discourses, such as those of economics, come into play.

\subsection{The Other Discourses}

The study found that in addition to the discourses in the analytical frame work two other discourses could be seen in several of the states. A discourse concerning size was seen in all the states other than Jersey, while a discourse of practicality was seen in Luxembourg and Åland.

\subsubsection{Size}

The discourse of size was in some cases difficult to separate from the discourses of identity as size is one of the factors in the states identities. However, it was clear in most of the cases that the discourse of size was a separate discourse and thus should be used as a separate analytical tool. The size issue was usually presented as being a disadvantage for the states. In other words the small size meant the state lacked strength or influence. This represents the perception of the EU as a power game. The power dimension is missing form the original analytical frame and the size discourse allows for its inclusion.. The discussion in Iceland about the ability of Iceland to influence the EU, were it to become a member state, is about relative power. Iceland, if it joins the EU would be the smallest member state and therefore concerned about the relative power of small states. The Andorran ambassador pointed to her states lack of influence with the EU as a direct result of the small size of Andorra and thus its lack of importance to the block. The inclusion of discourses of size as an analytical tool allows for the debate about small state power to be included.

Once size is included the question then arises about how size issues are resolved, Luxembourg gives an example of one end of the spectrum, that being small necessitates EU membership to have a voice on the European or global states, otherwise small states are ignored. Åland gives a counter point where the discourse included the lack of influence a small state can have within in the EU system. The debate in Iceland is trying to resolve if Iceland will loose or gain influence by joining the EU, the direction the discourse takes here may play a role in Iceland's future relationship with the EU. Andorra also shows this debate, but here the discourse includes the statement that Andorra is too small for full membership, thus the issue is how to maximise the available power for such a small state through some sort of association with the EU. 


\subsubsection{Practicality}

The practicality discourse was most clearly seen in Luxembourg. The Luxembourgian discourse gave practicality concerns a very high place. The danger with labelling this as a separate discourse is that it could be part of an economic discourse. However, the analysis in economic terms did not fit the perception of the interviewees who in this case saw EU membership as delivering practical benefits that were not necessarily simply economic but included a day to day easing of tasks. Åland also saw similar aspects to the debate, particularly about the common currency; here it was noticed most because one of the closest neighbours did not use the common currency. It is worth noting that it is the two EU members who have the discourse of practicality, it is of course understandable that those who are not members have no experience of the practicalities of EU membership and thus the discourse does not exist. It would be of interest to note if the newer member states have developed this discourse.

\subsection{General Conclusions}

The first aspect of the research question of what the content of discourse was in the small states under study has been answered with the empirical data collected by the interviews. The second aspect of the question of how this discourse has affected the relationship with the EU has been discussed to some degree in each chapter and again in the conclusions above. The summary below provides an overview of the conclusions and serves to introduce the following section examining the hypothesis.

As has been noted above the role of the identity discourse seems to be linked to the positivity or negativity of the debate about EU membership. If the identity questions have been resolved to a degree where other discourses can start then EU membership becomes possible. Andorra gives an example of where identity questions have been resolved to allow for membership but then a discourse of size has limited possibilities of further integration to something below membership. Thus it can only be concluded that Identity discourses can be a block to a change in relationship but their successful resolution does not mean membership will happen. Following the compatibility of identity discourses with membership the other discourses must also be compatible with the change in relationship with the EU. Of the other discourses this study points to economic discourses as being the most important. Given the economic nature of the EU it is not wholly surprising that economics should play a large role in the discourse about EU membership. However, as Iceland demonstrates it is not the only discourse that is important. The lack of a strong discourse of security, as discussed above, does not preclude its importance and most likely reflects a bias of the selection in this thesis, only further study could tell if its role is as important as originally assumed. 


\subsection{Examination of the Hypothesis}

The original hypothesis was:

'Small states seek to join the EU when questions of Security, Economics and Identity have been addressed. Once these three factors have been satisfactorily addressed in the National discourse then the state will seek membership of the EU.'

The research carried out has not entirely supported this hypothesis, thus it must now be address and changed. As noted in the analysis and conclusions above, the identity discourse has a potentially blocking role to the creation of other discourses so it must be moved into a more prominent place in the new hypothesis. However, as has been observed, once the discourse on national identity is seen as compatible with a change in status of relationship with the EU its prominence recedes. The other discourses then become the main focus; in particular this study found the economic discourse to be important. The other important factor to consider is the original direction of the hypothesis was one way. The hypothesis only dealt with states that were seeking a closer relationship with the EU. The data from Luxembourg points to a similar blocking pattern of the identity discourse for states that are already in the EU, in addition the Alland data points to the role of the other discourses in maintaining a position in favour of membership of the EU even when identity issues would allow for movement in either direction. Thus the new hypothesis must allow for movement in either direction. The new hypothesis should be formulated as:

'Once the discourse of national identity is compatible with a change in the relationship with the EU, then other discourses such as security, economics, size and practicality become the decisive factors of how a relationship with the EU will change.'

The reason this remains a discussion of hypotheses and not of theory is because the small number of states studied does not give the researcher confidence to create theory. However, the discussion below on further study gives an outline of how a theory could be created based on the above hypothesis. 


\section{Limitations and Further Study}

\subsection{Limitations}

The method of data collection gives rise to the biggest limitation of the thesis. The data collection method is potentially skewed in favour more international and better educated people. In all the states except Jersey the interviewees were asked to speak a language other than their mother tongue. Though it is worth noting that two of the interviews in Luxembourg took place in French, and these interviews gave results that were in tune with the other interviews from Luxembourg, likewise parts of the interviews in Åland were in Swedish and these gave the same results as those that were entirely in English. This being said the potential bias in the method should be considered. In all cases except Iceland and Andorra the interviews took place only in the capital city. This again gives a potential bias towards one particular view point since it may be possible that a particular section of society dominates in the capital which is absent in the rest of the state. The advantage to studying such small states is that the capital often has a large amount of contact with the rest of the state and the population is on average more homogeneous than in larger states. It is worth commenting at this stage that while it is unscientific the sampling 'method' used in the research sought to balance the ages and gender spread of the interviewees. In addition the number of locations of interviews, indicated in table 1.1, shows the attempt to ensure a spread of social groups within the cities that the interviews took place.

The relatively small number of interviews can lead to a problem of generalisability, however as was discussed in the methods chapter the unique quality of the method is that it allows for generalisation from this low number of cases since the object understudy is a discourse that is used by the population at large and thus as in all the states the interviewees gave answers that are consistent it is likely that the true discourse has been uncovered.

The original intent of the method was to also use media coverage of the relationship between the small states and the EU, however this did not prove to be practible since it would have required extensive translation of media for most of the states and thus this aspect of the study was removed. While this would have been an insightful part of the study it does not invalidate the current results it shows an area that is lacking. 
The analytical framework created pre-existing categories for analysis. There is a potential bias built into this form of analysis since the data that fits into the categories is likely to be over emphasised in comparison to data that does not fit into the categories. The creation of the $4^{\text {th }}$ analytical category of other themes which was re-analysed separately seeks to address this by allowing for new analytical themes to be introduced at any point in the process and thus hopefully overcomes the potential bias. The creation of two new analytical categories out of the fourth category hopefully shows that this was successful in avoiding this potential bias.

The data from Åland and Jersey has been assumed to show a discourse that is unique to these two island states. However, as neither is fully independent there remain questions as to how much the national discourse of the Great Britain or Finland has an impact on the local discourses in both places. There is no attempt in this thesis to examine the effects of their parent states on the local discourse. Similarly while Andorra is independent it forms a part of the Catalan media market and thus there is a potential effect of discourses from the Catalan region of Spain 'leaking' into the national discourse of Andorra.

The other remaining question that must be asked of this thesis is, does it tell us anything about small states? The original intent was to examine small states, and only small states by the definition set out at the start of the thesis have been studied. However, as the study has not considered any larger states there is no way to know if the findings tell us anything different about small states form larger states or if these patterns would be repeated in larger states. The assumption of the thesis is that even if these patters do exist in larger states they are not as dominant since the larger population leads to more competing discourses and thus the role of the individual discourses is diminished in comparison to the smaller states, this is however, merely supposition by the researcher and further study would need to be carried out to verify or falsify this.

\subsection{Further Study}

The single most obvious area for further study is the other small states and state like entities that have not yet been studied. The inclusion of these into a similar study would allow the researcher to establish if there are patterns across these states which are stable and then in comparison with larger states it may be possible to draw conclusions about what effect size has on the states in question, given the caveat above about needing a comparison to other larger states before conclusions about size can be drawn.

An additional potentially interesting future research point is the change in discourse over time. This type of research project would be more interested in the production of the discourse. This type of research would be preoccupied with how 
and why the discourse is produced and how and why any changes in the discourse occur. The example in this study of Iceland would be a good case study for this type of research given the current volatile nature of the discourse in Iceland.

The new hypothesis generated in the conclusions section could form the basis of a continued study of a larger number of small states and state like entities to test this hypothesis and see if theory can be generated from the new data. 


\section{Executive Summary}

\subsection{Definitions and Method}

The thesis addressed the question of what is the content of discourse within small states in Europe about the EU and how has that discourse affected relationships with the EU?

Using the main international relations theories of Liberalism, Realism and Constructivism, the analytical categories of economics, security and identity have been created and the hypothesis is, 'Small states seek to join the EU when questions of Security, Economics and Identity have been addressed. Once these three factors have been satisfactorily addressed in the National discourse then the state will seek membership of the EU.' Following the production of the hypothesis the thesis defines the small states as states with a population of less than two million. This limit has been chosen based on the work of Tina RandmaLiiv (2002) who gives a public administration definition of small states. She argues the limited size of society creates a different kind of public administration reflecting, the limitations a small population places on the functioning of government. Thus, these small states are not large states in miniature but are fundamentally different.

The object under study is the national discourse about the EU in each of the states. A definition of discourse as all encompassing is taken from the work of Michelle Foucault (1977). The method of interviewing 'non experts' who do not have academic frames to view the EU discourse through is created from this definition of discourse. By interviewing people in each state who are not trained 'experts' in the EU the thesis gains access to the national discourse. The results from the interviews can be generalised to the population of the state as a whole since the discourse is all entrapping and thus the way individuals talk about the EU in each state will be governed by the discourse.

In addition to the interviews with 'non experts' in each state, interviews with experts were carried out. This second set of interviews examined the way the 
relationship between the EU and the state in question functions in reality, this has been called the informal relationship. The formal relationship has been defined as the treaty arrangements or agreements between the state and the EU, while the informal relationship is defined as how the state seeks to influence the EU or how the formal arrangement actually works on a day to day basis.

The definition of small states was broadened to include state like entities. These are entities which while not formally independent, but have a high degree of autonomy and have chosen their relationship with the EU independently from the rest of the state they are part of. The small states of Europe were grouped by their formal relationship with the EU and then limited to only Western European states. This limitation was done to generate a practicable number of states for the study. Then one of each class was chosen, and this created the sample for the study of: Andorra, Iceland, Luxembourg, Jersey and Åland.

\subsection{Results and Analysis}

\subsubsection{Andorra}

The national discourse in Andorra was dominated by economic concerns, including marinating the low VAT rate and building a social security system. The identity of Andorra was cast as being an identity based on economic difference while security was only mentioned by a small number of interviewees and was always seen as a benefit of being outside the EU. The general discourse in Andorra was favourable to a closer relationship with the EU but within practical limits imposed by size. The discourse of size was the most prominent discourse that existed outside the analytical frame in any of the states studied.

\subsubsection{Iceland}

The national discourse in Iceland was dominated by the effects of the global economic crisis. Iceland had been very badly hit by the crisis and one of the dominant themes in the debate following the collapse was whether Iceland would have been better protected from the effects had they been EU members and had the Euro as the national currency. Other themes included the freedom of Iceland to make decisions for itself independently and retain control over vital resources such as fisheries. The security theme was not mentioned in Iceland and like Andorra the size discourse was also prominent. 


\subsubsection{Luxembourg}

The discourse in Luxembourg was very positive towards a continued close relationship with the EU. This positivity towards the EU was framed in economic terms mostly since the interviewees in Luxembourg felt that the state could not survive without the trade benefits from the EU. There was also a discourse of security derived from EU membership and Luxembourg's identity was seen as being wholly compatible with EU membership to the point where any change away from the EU would have threatened the identity of the state. In addition to the three discourses from the analytical frame, there were discourses of size and practicality. The size discourse included an idea of Luxembourg's need for the EU because of its small size and therefore lack of influence. The practicality discourse focused on the day-to-day easing of life that EU membership brought.

\subsection{4 Åland}

The discourse in Åland was slightly less economically focused than the previous states, here the Euro was the main focus as a positive economic benefit. Though, it should also be noted that the Euro was also seen in a discourse of practicality, like Luxembourg, as a very positive aspect of EU membership. In Åland even the most euro-sceptic interviewee did not wish to see the islands leave the EU but there was a feeling that the EU did not understand the unique identity of small islands and peripheral regions like Alland. The focus of this feeling of lack of understanding in Alland was the EU's ban on out of season bird hunting. The Ålandish discourse was not as strongly focused as those in Luxembourg or Iceland, which reflects the lack of current debate or controversy in Åland over EU membership.

\subsubsection{Jersey}

In contrast to all the other states under study the discourse in Jersey did not include economic matters with a very high priority. The identity discourse in Jersey was very strong, and seen as completely incompatible with EU membership. The interviewees in Jersey had no real knowledge of what EU membership would mean for the island and beyond the lower tax rates no real idea of what advantages there were to being outside of the EU, however all the interviewees were sure that the island should not join the EU. 


\subsubsection{General Conclusions}

The thesis finds that the economic discourse is very strong in most of the states; however, the discourses of security, size and practicality are of varying importance in the states too and can not be ignored. However, the most important discourse is that of identity, only once the identity discourse is compatible with a change in relationship with the EU is it possible for the other discourses to have an influence. Thus, the initial hypothesis is re-examined and the following is created:

'Once the discourse of national identity is compatible with a change in the relationship with the EU, then other discourses such as security, economics, size and practicality become the decisive factors of how a relationship with the EU will change.'

Due to the small number of states studied the thesis does not with to call this a new theory but suggests the continued study of small states to establish if this pattern holds across Eastern European states and the states in the West that have not yet been studied. 


\section{References}

Cole R., 2009. We Need a Total Opt-out from 'EU Militarization'. Irish Times Online. Available from:

http://www.irishtimes.com/newspaper/opinion/2009/0410/1224244360411.html [accessed 12.04.09]

Commission, 2004. Agreement Between the European Community and the Principality of Andorra providing for measures equivalent to those laid down in Council Directive 2003/48/EC on the taxation of savings income in the form of interest payments. Brussels: European Commission (Document Number L359/33)

Commission, 2005. Co-operation Agreement Between the EU and Andorra. Brussels: European Commission (Document Number L135/14)

Commission, 2006. Commission Takes Legal Action against Illegal Bird Hunting. Rapid Press Release. European Commission: Brussels (Document Number IP/06/879)

Available from:

http://europa.eu/rapid/pressReleasesAction.do?reference $=I P / 06 / 879 \&$ format $=H T$

$\underline{\text { ML\&aged }=0 \text { \&language }=\text { EN\&gui }}$

Commission, 2009. Iceland. Brussels: Commission External Relations. Available from: http://ec.europa.eu/external_relations/andorra/index_en.htm [accessed 18.02.09]

Council Directive 2006. Article 6 of Council Directive 2006/112/EC of 28 November 2006 (as amended) on the common system of value added tax. Brussels: European Commission (Document Number OJ L 347)

Crowards, T., 2002. The comparative size of countries within Europe. Status. Cooperation and Conflict, 6 (1) 91-102.

Elgström, O, \& Jönsson C., 2000. Negotiating in the European Union: bargaining or Problem Solving. Journal of European Public Policy 7 (5) 684 - 704.

Emerson, M., 2007. Andorra and the European Union. Brussels: CEPS

Eurobaromater, 2000. How the Europeans see themselves. Looking through the mirror with public opinion surveys. Brussels: European Commission. 
Flick, U., 2006. An Introduction to Qualitative Research. Third Edition. London: SAGE Publications.

Foucault, M., 1977. Discipline and Punish. New York: Pantheon .

Ingebritsen, C., 1998. The Nordic Countries and European Unity. Ithaca, NY: Cornell University Press.

Ingebritsen, C., 2006. Scandinavia in World Politics. Rowman and Littlefield: Lanham.

Jorgensen, M. \& Phillips, L., 2002. Discourse Analysis as Theory and Method. Sage: London.

Kagan, R. 2003. Of Paradise and Power: America and Europe in the New World Order. New York: Knopf.

Katzenstein P. J., 1995., Small States in World Markets: Industrial Policy in Europe. Ithaca: Cornel University Press.

Kennedy, P. 1991. 'Grand Strategy in War and Peace: Toward a Broader Definition' in P. Kennedy, ed., Grand Strategies in War and Peace. New Haven: Yale University Press. 1-7.

Kvale, S., 1996. InterViews: An Introduction to Qualitative Research Interviewing. Sage: London.

Laurent, P. H., 1982.. Small states Diplomacy and European Integration: The Beneluxers and the move toward economic union. Europa 5 (2) 263-270.

Lessa 2006. "Discoursive struggles within social welfare: Restaging teen motherhood". British Journal Of Social work 36: 283-298.

Mattilla, M. \& Lane, J., 2001 Why Unanimity in the Council? A Roll Call Analysis of Voting. European Union Politics 2 (1), 31-52.

Mouritzen, H. \& Wivel, A., 2005. The Geopolitics of Euro-Atlantic Integration. London: Routledge.

Morgenthau, H., J. 1972. Science: Servant or Master? New York: New American Library

Neumann, I., B. \& Gstöhl, S. 2004. Lilliputians in Gulliver's World: Small States in International Relations. Reykjavík: Centre for Small State Studies. 
Official Journal of the European Union 1995. Protocol 2 (on the Aland Islands) of the Finnish accession treaty. Brussels: European Commission (Document Number OJ C 241)

Pace, R., 2001. Microstate Security in the Global System EU Malta Relations. Valletta: Midsea Books.

Randma-Liiv, T., 2002. Small States and Bureaucracy: Challenges for Public Administration. Trames, 6 (4) 374-389.

Riddervold, M. \& Sjursen, H., 2006. The Importance of Solidarity: Denmark as a Promoter of Enlargement. In: H. Sjursen ed. Questioning EU Enlargement: Europe in Search of Identity. London \& New York: Routledge 81-103.

States of Jersey 2009. Jersey's Relationship with the EU. Available from: http://www.gov.je/HomeAffairs/CusAndImm/Customs+and+Excise/Traders+Info

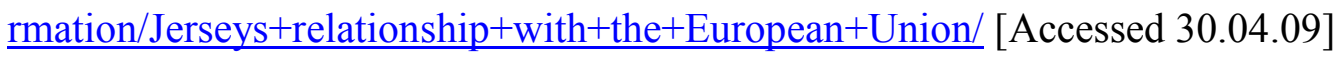

Thorhallsson, B., \& Wivel, A., 2006. Small States in the European Union: What Do We Know, and What Would We Like To Know? Cambridge Review of International Affairs, 19 (4), 651 - 668.

Time and Date 2008. Jersey Rejects Central European Time. Stavanger: Time and Date AS. Available from: http://www.timeanddate.com/news/time/jersey-timezone-referendum.html [Accessed 16.03.09]

Vayrynen, P., 1971. On the Definition and Measurement of Small Power

Watson, A. 1982. Diplomacy: The Dialogue between States. London: Methuen. 